\title{
Comparative study of durability of hybrid direct carbon fuel cells with anthracite coal and bituminous coal
}

\author{
Cairong Jiang, ${ }^{a}$ Jianjun Ma, ${ }^{a}$ Ana Arenillas, ${ }^{b}$ A. Damiano Bonaccorso ${ }^{a}$ and John T. S. Irvine ${ }^{a^{*}}$ \\ ${ }^{a}$ EaStCHEM, School of Chemistry, University of St Andrews, St Andrews, Fife, KY16 9ST, UK \\ ${ }^{b}$ Instituto Nacional del Carbon INCAR-CSIC, Apartado 73, 33080 Oviedo, Spain
}

Abstract

Direct carbon fuel cells offer the opportunity of generating energy from coal at high efficiency as an alternative to the procedure of conventional power plants. In this study, raw anthracite coal and raw bitumingus colal were investigated in a hybrid direct carbon fuel cell (HDCFC), which was a combination of a solid oxide fuel cell and a molten carbonate fuel cell. Mechanical mixing was confirmed to be an efficient method of mixing coal with carbonatef The coal samples had different properties, for example, carbon content, hydrogen content, volatile matter and mprurities. The results showed that the maximum power density obtained by the cell with anthracite coal was similar to that obtained be the cell with bituminous coal. It was found that the total power output from coal in HDCFCs mostly depended on the carbon content, while volatile matter, hydrogen content, moisture, etc. had an effect on the short-term durability. HDCFCs were kept operating for more than 120 hours with $1.6 \mathrm{~g}$ coal. This study demonstrates that energy can be generated efficiently by employing anthracite and bituminous coal in hybrid direct carbon fuel cells.

Key words: Direct Carbon Fuel Cells, Anthracite coal, Bituminous eal, Maximum Power Densty, Qurability

\section{Introduction}

Coal is an abundant fossil fuel in many countries and it supplies most of ourgobakenergy. About three-quarters of the electricity generated in the UK comes from power stations fuelled by foss lifuels. As a major fossil fuel, coal will continue to be used for the generation of electricity in the near future, despite growng concerns about the effects of greenhouse gas emissions. A practical way of using coal more efficiently is to generate more energy per unit of coal, as far as the environmental impact is concerned. This coukd be achieved by direct oxidation of coal in a fuel cell to produce electricity. A fuel cell using darbon direcky as a fuel withou externangasification is defined as a direct carbon fuel cell (DCFC). This device works on the basis of an exectrochemical process yather than on combustion. A DCFC theoretically has a high electrical efficiency, because of its the high electronentical gonversion efficiency, slightly in excess of $100 \%$ due to a positive entropy change for the celtreaction. Practicalsystens ean reach an overall efficiency as high as $80 \%$, which is a major improvement over the current $40 \%$ efficiency from traditional coal fired power plants. Moreover, DCFC systems are not only scalable, hence suitable for decentralised prodricity production, but also quiet, due to the absence of rotating parts.

The first attempt to develop a process for electidity generation from coal was made by Jacques in $1896^{1,2}$. Recent work on coal fuel cels was renewed by the energy demands for the reduction of $\mathrm{CO}_{2}$ emissions. Researchers have focused on the application of different types of coar sandes in DCFCs ${ }^{3,4}$. So far, lignite, bituminous and anthracite coal have been tested

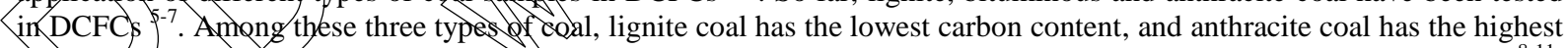
caxbon/content. In literature, ash-free coal samples were selected for DCFCs in order to avoid the effect of impurities ${ }^{8-11}$. When these were fed into a molten carbonate fuel cell and gasified mainly to hydrogen and carbon monoxide and it seemed that the gasification of coal was more dependent on the temperature than on the presence of carbonate. ${ }^{8}$ The gasification of lignite was sensitive to the carrier gas. In the presence of $\mathrm{CO}_{2}$, lignite was gasified into $\mathrm{CO}$ at $800{ }^{\circ} \mathrm{C}$, and therefore, resulted in a good cell performance ${ }^{12}$. Anodic electrode composition, carrier gas composition and flow rate, and a carbonate addition were important parameters and these were therefore optimised. Although the feasibility of employing lignite was explored in literature, the poor performance would require further investigation. Raw coal without pre-treatment has been used directly in DCFCs. Demineralized coal washed with $\mathrm{HNO}_{3}$ was also investigated as a fuel in a YSZ electrolyte-supported cell with a Ni-GDC-YSZ anode ${ }^{13,14}$. A maximum power density of $33.3 \mathrm{~mW} \mathrm{~cm}^{-2}$ was obtained with raw coal fuel when the cell was operating at $850^{\circ} \mathrm{C}$. A similar maximum power density was achieved with demineralized coal, but with better durability in $\mathrm{N}_{2}$ as compared to that of raw coal fuel. The fast degradation rate with raw coal was attributed to its ash accumulation on the anode surface, and also to the continuous carbon consumption ${ }^{14}$. In our previous research, different types of coal were selected for a primary test in hybrid DCFCs ${ }^{3,15,16}$. Lignite coal, bituminous coal and anthracite coal were evaluated in a button cell with a NiO-YSZ anode, a YSZ electrolyte and a LSM-YSZ cathode. The bituminous and anthracite coal had shown good durability over two hours of testing compared to the lignite coal ${ }^{15}$. We also investigated the application of ternary carbonate of lithium, sodium and potassium carbonate with a molar ratio of 43.5:31.5:25 in HDCFCs. The cell was tested at relatively low temperature of $700{ }^{\circ} \mathrm{C}$ and the power output generated was similar to that of the cell with binary carbonate operating at $750{ }^{\circ} \mathrm{C}{ }^{16}$. As one of the main types of coal, anthracite coal is suggested as a good candidate for DCFCs due to its high carbon content, usually is above $90 \%$, but there are not many publications about anthracite fuel for DCFCs. ${ }^{3,4}$ In our previous research, we initially discussed the effect of chemical compositions (e. g. carbon content, 
hydrogen content, etc.) on the electrochemical performance, concentrating mainly on maximum power density and shortterm durability ( 2 hours). In the light of this work, we will now intensively investigate the utility of anthracite coal in this study. We will focus on the comparison of anthracite coal with bituminous coal as a fuel for hybrid DCFCs in terms of maximum power density, short-term (24 hours) and long-term durability (over 100 hours).

\section{Experiments}

\subsection{Coal properties}

The sample was chemically characterized by means of elemental analysis ( $\mathrm{C}, \mathrm{H}, \mathrm{O}, \mathrm{N}$ and $\mathrm{S}$ wt $\%$ content) with a LECO CHNS-932 analyser. The oxygen was determined with a VTF-900; proximate analyses (volatile matter, ash and moisture content) were also evaluated and the ash composition was determined by x-ray fluorescence in a Brukex SRS 3000 . The petrographic compositions of all the coal samples are shown in Table 1.Table 2 summarises the chemica compositions and Table 3 lists the ash composition of all the coal samples. These four coal samples have significantydifferent properties, such as carbon content, sulphur content and ash content. For carbon content: A-I>B-II >B-I $>$ A-II; salphux content: A-II $>$ AI $>$ B-I=B-II; ash content A-II $>$ A-I $>$ B-II $>$ B-I; hydrogen content $\mathrm{B}-\mathrm{I}=\mathrm{B}-\mathrm{II}>\mathrm{A}-\mathrm{II}>\mathrm{A}-\mathrm{I} />$

Table 1 Petrographic composition of all the coarsamples

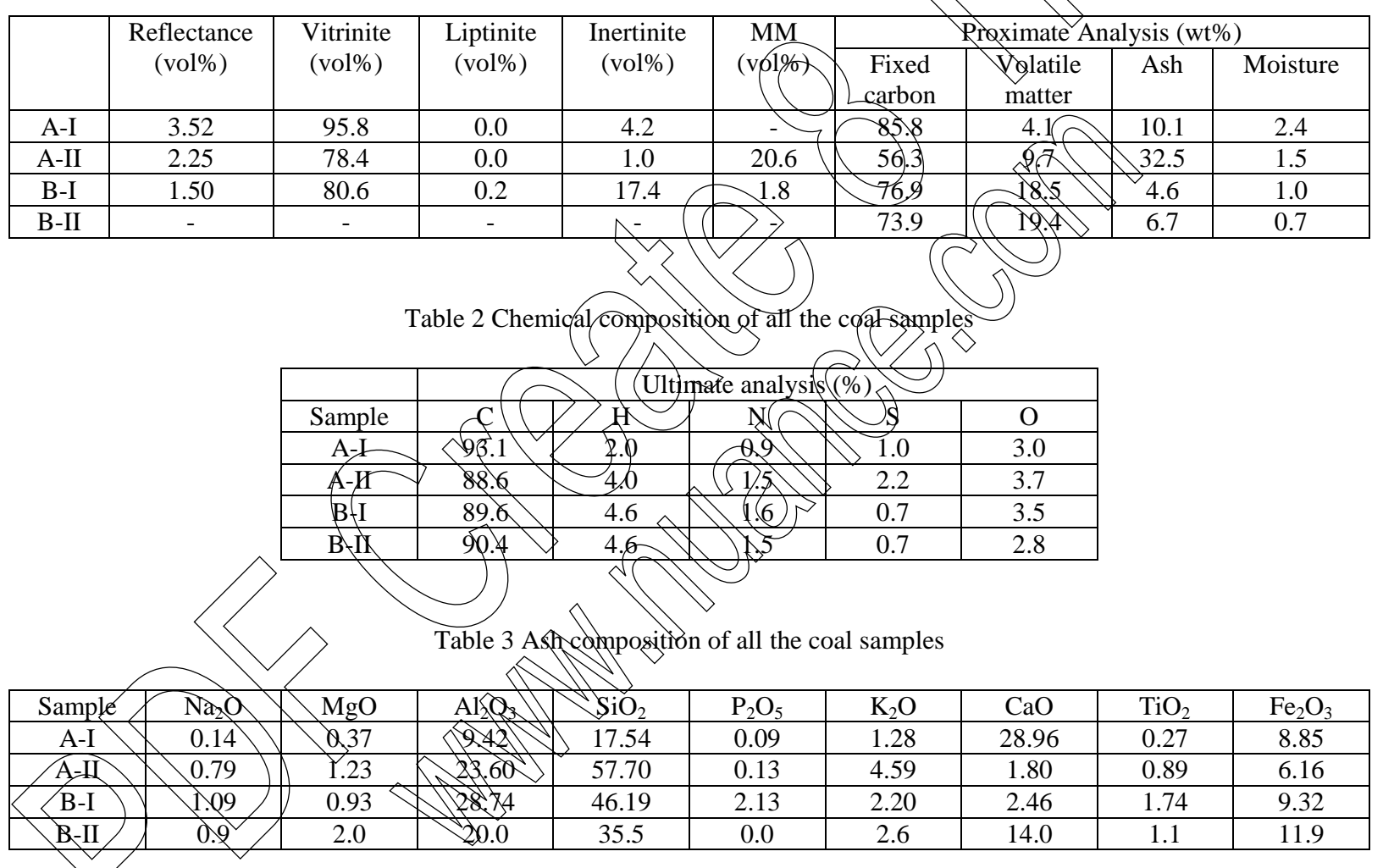

A Fourier Transform Infrared spectrophotometer (FTIR; Shimadzu, IRAffinity-1S) was used for the FTIR spectra measurements. Figure 1 shows the data recorded between 4000 and $400 \mathrm{~cm}^{-1}$ with 100 scans and a resolution of $4 \mathrm{~cm}^{-1}$. These two anthracite coal samples have a similar structure and A-I has fewer peaks than A-II. The band at $1595 \mathrm{~cm}^{-1}$ is assigned to the C-C stretching vibration in aromatic groups and the band at $1029 \mathrm{~cm}^{-1}$ is ascribed to the C-O stretching vibration. The bands lower than $1000 \mathrm{~cm}^{-1}$ can be attributed to the $\mathrm{C}-\mathrm{H}$ stretching vibration in aliphatic and aromatic compounds. Compared to anthracite coal, bituminous coal samples have more bands shown in FTIR spectra. Apart from the same bands shown above, the band at $3431 \mathrm{~cm}^{-1}$ is attributed to the $\mathrm{O}-\mathrm{H}$ stretching vibration in hydroxyl functional groups, the bands at $2940 \mathrm{~cm}^{-1}$ and $1373 \mathrm{~cm}^{-1}$ are due to the asymmetric and symmetric C-H stretching vibration in alkyl compounds, and the band at $1695 \mathrm{~cm}^{-1}$ is due to the $\mathrm{C}=\mathrm{O}$ stretching vibration in aromatic compounds.

The X-ray diffraction (XRD) patterns of raw coal samples were recorded on a PANalytical Empyrean Reflection Diffractometer with $\mathrm{Cu} \mathrm{K} \alpha$ radiation $(\lambda=1.5418 \AA)$ using settings of $40 \mathrm{~mA}$ and $40 \mathrm{kV}, 2 \theta$ range of $10-90^{\circ}$, step size of 0.02 ${ }^{\circ}$ and scan step time of $2 \mathrm{~s}$. The results are shown in Figure 2. 
These two anthracite coal samples present a distinct diffraction peak at 20-30 ${ }^{\circ}$, which corresponds to the (002) reflection of carbon. Another peak at around $44^{\circ}$ is attributed to the (100) graphite crystal face reflection. In addition to the carbonaceous diffraction peaks, the diffraction peaks correspond to minerals in the anthracite coal samples. Both of these anthracite coal samples have quite a high ash content (Table 3). Quartz is one of the main impurities and two extinguish peaks are present at $20.5^{\circ}$ and $26.4^{\circ}$. Some other impurities are present, such as $\mathrm{Al}_{2} \mathrm{O}_{3}$, which exists in the form of kaolin. ${ }^{11}$ B-I and B-II have less ash content, therefore except for main peaks at $20-30^{\circ}$ and at $44^{\circ}$ few other peaks are identified. In the XRD patterns, organic components show broad peaks due to their lower crystallinity, while inorganic components display sharp peaks because of their higher crystallinity. The two broad peaks at $20-30^{\circ}$ and $44^{\circ}$ are typical examples of carbon and other peaks are due to the presence of inorganic components in the coal samples, as listed in Table 3.

\subsection{Mechanical mixing of coal with carbonate}

The carbonate mixture was obtained by mixing a $62 \mathrm{~mol} \%$ lithium carbonate (Aldrich Chemical Co. WI, USA) with a 38 mol\% potassium carbonate (Fisher, UK).

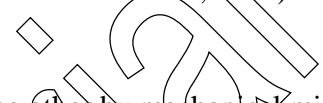

Two methods were used to mix the carbonate with the coal samples, one by hand, And the other by medhangalmixing in a ball mill. For the hand mixing process, a eutectic carbonate mixture was mixed in mortar with the coansample. For the mechanical mixing process, the eutectic carbonate mixture was mixed in a ball millfor 24 hours with the coal sample, using acetone as a solvent. The weight ratio of coal to carbonate was 4:1. The resultant mixture was thendried overnight in an oven at $80^{\circ} \mathrm{C}$.

\subsection{Cell preparation and electrochemical characteristics}

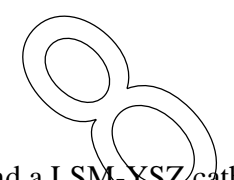

Solid oxide fuel cells using a NiO-YSZ anode, a YSZ electrolyte and a LSM-KSZ cathode we used for the electrochemical tests. The details are shown in our previous paper. ${ }^{17} \mathrm{~A}$ YSZ (Pikem) exectrolyte with $1 \mathrm{~mm}$ theness was prepared using a dry-pressing method and sintered at $1500^{\circ} \mathrm{C}$ for 10 hours. NiQ A Adrich, 325mesh PSZ (Pikem) composite electrode ink with a $60 \mathrm{wt} \% \mathrm{NiO}$ and a $40 \mathrm{wt} \% \mathrm{YSZ}$ was screen printed an end side of the YSZ electrolyd ${ }^{\circ} \mathrm{C}$ for $2 \mathrm{~h}$. After this, a $\left(\mathrm{La}_{0.8} \mathrm{Sr}_{0.2}\right)_{0.95} \mathrm{MnO}_{3}$ (LSM,PRAXAIR)-YSZ composifeetectrode ink (LSM/YSZ=50:50) was screen printed on the other side of the YSZ electrolyte and sintered at 1100 C for $2 \mathrm{~h}$. The area of the anode and the cathode was the same, which was $1.13 \mathrm{~cm}^{2}$. After that, sitver paste was painted on the angte and the cathode side for current collectors, pre-calcined at $800^{\circ} \mathrm{C}$ for $1 \mathrm{~h}$. The cell wys sealed on an aning tureusing a sealant (Aremco 552), with the anode side on top. Two grams of this mixture of cal-carbonate fited into the anode chamber. The cells were heated to $250{ }^{\circ} \mathrm{C}$ in nitrogen and kept at this temperature for half an hourte cure the ceramic sealant, and then increased to $750{ }^{\circ} \mathrm{C}$. The flow rate of nitrogen was $15 \mathrm{ml} / \mathrm{min}$. The cels performance was measured on a Solartron $1280 \mathrm{~B}$ with $10 \mathrm{mV}$ ac amplitude for AC inhpedance and $20 \mathrm{mV} / \mathrm{step}$ to scan the curent-voltage curves. The short-term and long-term durability was tested at 0.7 After operating at $0.7 \mathrm{~V}$ for 2 hours, the ac impedance spectra and the I-V curves were recorded and the cell was then again tested for durability at $0.7 \mathrm{~V}$. Some of the cells were continuously tested at $0.7 \mathrm{~V}$ for 24 hours or until the fuel was firished. The tests were carried out as ons the cell was operating at $0.7 \mathrm{~V}$ for 2 hours, and then it was held in open circuit conditions for 20 mins and then ac impedance spectrum was collected, and then the loop was started again. Seyen cels from the same batch were tested indifferent conditions, as shown in Table 4.

\begin{tabular}{|c|c|c|c|c|c|c|c|}
\hline \multirow{2}{*}{ Cell } & \multirow{2}{*}{ Fuel } & \multirow{2}{*}{$\begin{array}{l}\text { Mixing } \\
\text { method with } \\
\text { carbonate }\end{array}$} & \multirow{2}{*}{$\begin{array}{l}\text { Short-term } \\
\text { durability } \\
\text { (24 hours) }\end{array}$} & \multicolumn{3}{|c|}{ Purge gas } & \multirow{2}{*}{$\begin{array}{c}\text { Long-term } \\
\text { durability } \\
\text { (over } 120 \\
\text { hours) }\end{array}$} \\
\hline & & & & 2 hours & 2-24 hours & After 24 hours & \\
\hline Cell I & A-I & Hand Mixing & Yes & $\mathrm{N}_{2}$ & $\mathrm{~N}_{2}$ & - & - \\
\hline Cell II & A-I-M & Hand Mixing & Yes & $\mathrm{N}_{2}$ & $\mathrm{~N}_{2}$ & - & - \\
\hline Cell III & A-I-M & $\begin{array}{l}\text { Mechanical } \\
\text { mixing }\end{array}$ & Yes & $\mathrm{N}_{2}$ & $\mathrm{~N}_{2}$ & No $\mathrm{N}_{2}$ & $\mathrm{No} \mathrm{N}_{2}$ \\
\hline Cell IV & A-II-M & $\begin{array}{l}\text { Mechanical } \\
\text { mixing }\end{array}$ & Yes & $\mathrm{N}_{2}$ & $\mathrm{~N}_{2}$ & - & - \\
\hline Cell V & B-I-M & $\begin{array}{l}\text { Mechanical } \\
\text { mixing }\end{array}$ & Yes & $\mathrm{N}_{2}$ & $\mathrm{~N}_{2}$ & $\mathrm{No} \mathrm{N}_{2}$ & $\mathrm{No} \mathrm{N}_{2}$ \\
\hline Cell VI & B-II-M & $\begin{array}{l}\text { Mechanical } \\
\text { mixing }\end{array}$ & Yes & $\mathrm{N}_{2}$ & $\mathrm{~N}_{2}$ & $\mathrm{No} \mathrm{N}_{2}$ & $\mathrm{No} \mathrm{N}_{2}$ \\
\hline Cell VII & A-I-M & $\begin{array}{l}\text { Mechanical } \\
\text { mixing }\end{array}$ & Yes & $\mathrm{N}_{2}$ & No & $\mathrm{No} \mathrm{N}_{2}$ & $\mathrm{No} \mathrm{N}_{2}$ \\
\hline
\end{tabular}




\section{Results}

\subsection{Effect of mechanical mixing processing of coal with carbonate}

The particle size distributions of the anthracite coal (A-I) as received are below 212 microns, as shown in Figure 3a. The particle size of the anthracite coal after milling (A-I-M) is below 75 microns with a narrow distribution (Figure $3 b$ ). All the other three coal samples, A-II, B-I, and B-II were milled to make sure that all particles are below 75 microns. The long term stability of the cell using the anthracite coal with different particle sizes is presented in Figure 4. The A-I-M fuelled cell (Cell II, Table 4) generates more power than that of the A-I (Cell I, Table 4) fuelled cell, as far as the long term durability is concerned (e.g. 24 hours). The cell with A-I-M had significantly better durability after 8 hours. The initial cell performance of Cell II is not as good as that of Cell I. The resistance of Cell II is $6 \Omega \mathrm{cm}^{2}$ (point C in insert graphin Figure 4), bigger than $4.5 \Omega \mathrm{cm}^{2}$ of Cell I (point A in insert graph in Figure 4). After 2 hours, the resistances of Cell II and CelN are $12.5 \Omega \mathrm{cm}^{2}$ (point D in insert graph in Figure 4) and $9 \Omega \mathrm{cm}^{2}$ (point B in insert graph in Figure 4), respectively. Thre electrochemical behaviour difference of these two cells (Cell I and Cell II) could be caused by the mixing nethod of the coal satuples with carbonate. Hand mixing was initially used in this instance to mix the coal samples with lithimmand potassiuntryarbonate in order to maintain the particle size of these two coal samples. But we expect mechanical nixing to be a nore efficient method than hand mixing, and therefore we develop a mechanical mixing method using anball mill formixing the coal sample with carbonate. The comparison of the impedance spectra of the cells by hand mixing (Cey N) and mechanical mixing (Cell III) is shown in Figure 5. It can be seen that Cell III with the coal milled in zirconia medium inacetone (Cell III, mechanical mixing, Table 4) has a smaller series resistance, which is only $3.27 \Omega \mathrm{cm}^{2}$ (Figure 5a). However if the coal sample is handmixed with lithium potassium carbonate in a mortar (Cell II, hand mixing, Dable 4), the series resistance of Cell II is $4.43 \Omega$ $\mathrm{cm}^{2}$ (Figure 5b). The electrochemical behaviour difference of these two cell could be caused by the wetting ability of the carbonate to carbon, occurring with the different mixing methods. Mechanical mixing means that cod has more chance of contact with the carbonate, thereby facilitating a more efficient reduction of the nickel teatrode by the fuel. Therefore, the series resistance of Cell III is much smaller than that of CellII, which/might be because CeN II is not reduced entirely. In the following experiments, mechanical mixing in the ball mikwill be used to mix the carbenate with coal samples.

\subsection{Electrochemical performance of the cell with different types of coal}

The electrochemical performance of the cell with difterent typess of coatis nown in Figure 6. Cell IV with A-II fuel has the biggest polarisation resistance, which is $1.84 \mathrm{Sem}^{2}$ (F g gure 6a) (the difference of the impedance spectra between the high frequency and low frequency/intereepts with the $X$-axis. In this study, impedance spectra have no intercept with $X$ axis at the low frequency, so the maximum values are used.). The polarisation (resistance of Cell V with B-I fuel is $1.37 \Omega \mathrm{cm}^{2}$ (Figure 6a). The cells with A-I or B-INhas the same polatisation resistance of $1.26 \Omega \mathrm{cm}^{2}$ (Figure 6a). The series resistance of the cells varies. They gre in the range of 3.19 to $3.54 \Omega \mathrm{cm}^{2}$ The differences could be caused by the slight differences in the thicknesses of the electrolyte, the contact resistance or the electrode resistance. In this study, the electrolyte-supported cells are used and therefote the ohmic resistance of the electrolyte is a major contributing factor to the series resistance. The YSZ pellets were prepared by the dry pressing method. Dhe slightly different series resistance of the cell could be due to the

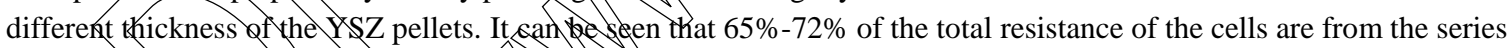
resistance. The electrochemical performance of the cell could be further improved if thinner YSZ electrolyte is used.

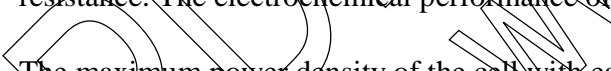

The maximum power density of the cenvith each coal sample is similar (around $60 \mathrm{~mW} \mathrm{~cm}^{-2}$ ). The highest maximum poted density of $71.88 \mathrm{~mW} \mathrm{~cm}^{-2}$ is obtained by the cell with B-II fuel. This power output obtained in this study is on the top level apong reports in literature concerning electrolyte-supported cells $\mathrm{s}^{4,12,18}$. The values achieved here are better than those of cells operating at a higher temperature $\left(850^{\circ} \mathrm{C}\right)$, even though a thinner YSZ electrolyte $(0.5 \mathrm{~mm})$ and a composite electrode of Ni-GDC-YSZ are used. ${ }^{14}$ This might be attributed to the presence of carbonate, which enhances both the gasification reaction and electrochemical reactions, as shown in equation (1) and (2).

$$
\begin{aligned}
& \mathrm{C}+2 \mathrm{CO}_{3}{ }^{2-} \rightarrow 3 \mathrm{CO}_{2}+4 \mathrm{e}^{-} \\
& \mathrm{C}+\mathrm{CO}_{3}{ }^{2-} \rightarrow \mathrm{CO}+\mathrm{CO}_{2}+2 \mathrm{e}^{-}
\end{aligned}
$$

\subsection{Short-term and long-term durability}

The durability of cells with different coal samples as fuels was recorded over a 24 hour period, and the results are shown in Figure 7a. The cells (Cell V and Cell VI) with bituminous coal (B-I or B-II) have a slower degradation rate compared to the cell (Cell III and Cell IV) with anthracite coal (A-I or A-II) in the first ten-hour period. After that, the durability of cells using different coal fuels show different trends. The performance of A-I fueled cell (Cell III) increases with time from 20 $\mathrm{mA} \mathrm{cm}{ }^{-2}$ to $45 \mathrm{~mA} \mathrm{~cm}^{-2}$ over the first 15 hours and then slowly decreases to $40 \mathrm{~mA} \mathrm{~cm}^{-2}$ over the remaining testing time. 
The cell with A-II fuel (Cell IV) demonstrates a quick drop from $80 \mathrm{~mA} \mathrm{~cm}^{-2}$ to $30 \mathrm{~mA} \mathrm{~cm}^{-2}$ in the first 5 hours and then degrades slowly thereafter the remaining time. B-I fueled cell (Cell V) shows some degradation in the first 8 hours and then remains almost a constant current until the operational testing reaches 17 hours. There is then a quick drop almost to zero in 3 hours. The cell with B-II fuel (Cell VI) shows a slow degradation over an operational time of 18 hours. The difference of the electrochemical performance is due to the various properties of bituminous coal and anthracite coal. There is less hydrogen content in anthracite coal than that in bituminous so that a slightly lower maximum power density is obtained in the beginning. This result is in agreement with the report from Xu et al. ${ }^{19} \mathrm{He}$ found that the electrochemical performance of lignite, bituminous and anthracite coals was in accord with the hydrogen content of these three coal samples. Lignite coal has the highest hydrogen content so that the best maximum power density was obtained by the cell with lignite coal fuel.

Volatile matter is another important parameter that might enhance the cell performance. There is a higher volatile content in bituminous coal than in anthracite coal. So the maximum power densities of both B-I and B-II are sightly higher than those of A-I and A-II. A quick performance loss on the cell with anthracite coal while the cell is operating in the first few hours might be because of less volatile matter in anthracite coal. The increase of the cell performance after that ispossibly related to the high carbon content. During the process of durability testing, coal devolatilisation is happening at the same time. In fact coal devolatilisation starts in the beginning of the heating of the cell. In the process of cpar devolatilisation, the coal structure changes and gases are produced. The gases of $\mathrm{CO}_{2}, \mathrm{CO}, \mathrm{H}_{2} \mathrm{O}$ and $\mathrm{CH}_{4}$ etc are reteased anow and intermediate temperatures. Some of these gases are produced before the electrochemical data are collected. Therefore due to the loss of these gases, the cells using coal samples with the highest volatile matter lose most ofthe coal faed A-I has the lowest volatile matter and the highest carbon content so that after a certain time (10 hours' durability test), it has the most carbon left for energy generation.

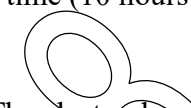

Another possible impact considered in this study is the purge gas. The electrochemical testing in Figure 7 was carried out in nitrogen. Figure 8 shows that a cell being tested in nitrogen for the first two hours and then nitrogen for the remaining time. It shows a quick performance drop in nitrogen and a sharp performance increase after the nitrogen is stopped. The cell is running stability at a constant valu $2 \mathrm{f} 40 \mathrm{~m} \mathrm{~A} \mathrm{~cm}^{-2} /$ over the test perigd. why e the cell running in nitrogen exhibits a performance drop after 8 hours (Figuke 7. Cell ur with A-I-M fuel). The ass consumption of the coal might be the main reason for the fast degradation in the nitrogent
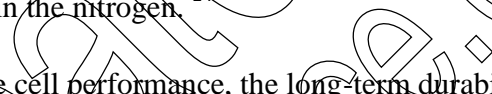

Due to the critical influence of the purge gas in the cell performance, the long-tern durability of cell III, Cell V and Cell VI without purge gas was recorded and the results are shown in Figure 9 . If ean be seen that the cell is running at 20-40 mA cm ${ }^{2}$ for over 120 hours with only $1.6 \mathrm{~g}$ of copal. The total power output with A-C uel is $3327 \mathrm{~mA} \mathrm{~h}$ (Cell III), while the total power output with B-I and B-IIfueris $2760 \mathrm{~mA}$ (Cell V) and $18(75) \mathrm{MAll}$ (C) VI), respectively.

The change of open circuit voltage was reforded for the anthracite coatfuelled cell which is shown in Figure 10. In the first 60 hours the open circuit voltage of cell remains constand and to not take long to regain its original value after the current load. After that, the open circult voltage of the cellakes Yonger to recover its original value, but it does not increase a lot. After120 hours takes much longer for the op circuits voltage of the cell to recover to its original value. After 145 hours the open circult vortage of the cell decrease voratically to $0.7 \mathrm{~V}$, which is the voltage used for durability testing. The cell fais because of the decrease in the opencircuit voltage. When the open circuit voltage decreases down to $0.7 \mathrm{~V}$, it is no longer able to sustain the operation so the cursentecreases dramatically at the end of the cell life. It is found that the coal thas finished by that time.

\section{Discussion}

It can be seen from the results of these experiments that the electrochemical reactivity of coal samples in direct carbon fuel cells is highly dependent on their physical and chemical properties, for example, their crystal structure, chemical composition and ash composition. The maximum power densities of the cells operating at $750{ }^{\circ} \mathrm{C}$ with four coal samples are similar (Figure 6). The B-II fuelled cell has a slightly higher power density than the other three coal samples. This could be due to its higher volatile matter $(19.4 \%)$. When it is scanning the current-voltage curves, volatile matter is released. The released gases of $\mathrm{H}_{2}, \mathrm{CH}_{4}, \mathrm{CO}$ and $\mathrm{CO}_{2}$ from the thermal decomposition of the volatile matter contribute to the electrochemical reactions. ${ }^{19} \mathrm{H}_{2}, \mathrm{CH}_{4}$ and $\mathrm{CO}$ can be oxidised by oxygen ions from the cathode,

$\mathrm{H}_{2}+\mathrm{O}^{2-}=\mathrm{H}_{2} \mathrm{O}+2 \mathrm{e}$

$\mathrm{CH}_{4}+4 \mathrm{O}^{2-}=2 \mathrm{H}_{2} \mathrm{O}+\mathrm{CO}_{2}+8 \mathrm{e}^{-}$

$\mathrm{CO}+\mathrm{O}^{2-}=\mathrm{CO}_{2}+2 \mathrm{e}^{-}$

These gases can also react with carbonate electrochemically: 
$\mathrm{CO}+\mathrm{CO}_{3}{ }^{2-} \rightarrow 2 \mathrm{CO}_{2}+2 \mathrm{e}^{-}$

$\mathrm{H}_{2}+\mathrm{CO}_{3}{ }^{2-} \rightarrow \mathrm{H}_{2} \mathrm{O}+2 \mathrm{CO}_{2}+2 \mathrm{e}^{-}$

Lee et al. tested different coal samples in a MCFC-DCFC and he found that the maximum power density was related to the volatile matter. ${ }^{20}$ The cell using coal with $50 \%$ of volatile matter generated $114.1 \mathrm{~mW} / \mathrm{cm}^{2}$ maximum power density, while, using coal with $30 \%$ of volatile matter, it only achieved a maximum power density of $111.1 \mathrm{~mW} / \mathrm{cm}^{2}$. For carbon black that has no volatile matter, the maximum power density was $106.76 \mathrm{~mW} / \mathrm{cm}^{2}$. Similar results were reported by Xu et al. by using three coal samples of lignite, bituminous and anthracite coals. The cell performance at a lower temperature $\left(750{ }^{\circ} \mathrm{C}\right)$ was significantly different to that at the high temperature $\left(850^{\circ} \mathrm{C}\right)^{19}$. Lignite coal has the highest volatile matter $(37.14 \%)$, so the cell generated the highest power density at $750{ }^{\circ} \mathrm{C}$. Anthracite coal has the lowest volatile matter (16.09\%) and therefore produced a lower power density. ${ }^{19}$

In terms of the durability (24 hours), the power output exhibits huge differences. Figure 11 show thexelationship of the power output with the chemical composition of then coal samples over a period of 24 hours. It generates $\$ 40 \mathrm{~m} \$ \mathrm{~h}, 664 \mathrm{~mA}$ $\mathrm{h}, 761 \mathrm{~mA} \mathrm{~h}$ and $785 \mathrm{~mA} \mathrm{~h}$ for cell III, Cell IV, Cell V and Cell VI, respectively. It is clear that the power output of the cell over 24 hours increases with the amount of volatile matter, as shown in Figure 11 a. It is therefore believed that the volatile matter is beneficial to the cell performance in the short term. The influence of yolatite matter ph cell performance has been confirmed in previous research. ${ }^{3,10} \mathrm{Ju}$ et al. investigated coal and ash-free coal fuelled button cens yith a Ni-YSZ anode. At $750{ }^{\circ} \mathrm{C}$, a double cell performance was obtained with a raw coal fuelled cel when compared to an ash-free coal fuelled cell $^{10}$. This was attributed to the volatile matter in raw coal producing gases in the thermal deeomposition of these organic compounds.

The ratio of hydrogen to carbon follows the same trend as the volatile matter in Figure 11b. It is deemped that the highest activity of bituminous coal is associated with its high ratio of oxygeng carbon and hydrogen content. Predtechensky et al. established the relationship between the maximum power density of the cell and the hydrogen content of the solid carbon fuel in a molten carbonate fuel cell. ${ }^{22}$ Among cannel coal, anthracite and graphite, cannel cogal had the highest hydrogen content, therefore, the best maximum power density of the cell was obtained with this coat. Moisture is another parameter to be considered, and this has been plotted with the relationship of power outputover a period of 24 hours in Figure 11c. The power output decreases as the moisture increases. Coal with a) low sulphur dontent (Figure 11d) or a low ash content (Figure 11e) produces more power energy. This is in agreendent with the resul we oforined in previous research ${ }^{3}$. Not only the ash content, but also the ash compositions have an essential effect on the performance. There have been some reports about the impact of impurities on the cell performance. Some of these degrade the anode materials and some of them act as catalysts. In a study of DCFC with raw coan and ash-free con as a found to cause a significant side-effect on the long term durability ${ }^{10}$, mainly due to the blocking of the porestructure and the inhibition of the anode reaction. The presence of the impurities of quartz and $\mathrm{Al}_{2} \mathrm{O}_{3}$ prevents gasification thereboventing the reactant gas from contacting the carbon surface. $\mathrm{Mn}_{2} \mathrm{O}_{3}, \mathrm{CeQ}_{2}, \mathrm{Ag}_{2} \mathrm{O}$ have been reported to act as catolysts in a hybrid direct carbon fuel cell with bituminous coal as the fuel and it has been found that these additimes geaty improved the activities of coal oxidation ${ }^{6} . \mathrm{MgO}, \mathrm{CaO}$ and $\mathrm{Fe}_{2} \mathrm{O}_{3}$ exhibit catalytic propertie in molten carbonate

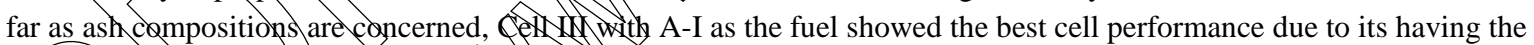
highest $\mathrm{CaO}$ ampount (28.96\%) and the onest $\mathrm{Al}_{2} \mathrm{O}_{3}(9.42 \%)$ and $\mathrm{SiO}_{2}(17.54 \%)$ content. It might also be due to its high carbon content as well as its more ordened arystalline structure. Fixed carbon content represents the energy that can be praduced from coak Therefore, more power output is obtained from coal with a higher fixed carbon content. Cell IV with AII as the fuel shows the lowest electrochemical reactivity due to its high amount of $\mathrm{SiO}_{2}$ and $\mathrm{Al}_{2} \mathrm{O}_{3}$. Cell VI with B-II displays ahigh cell performance due to its high content of $\mathrm{CaO}(14.0 \%), \mathrm{MgO}(2.0 \%)$ and $\mathrm{Fe}_{2} \mathrm{O}_{3}(11.9 \%)$. Some small amount of ash composition, like $\mathrm{P}_{2} \mathrm{O}_{5}$, is deemed to have a side-effect on the cell performance. There is no $\mathrm{P}_{2} \mathrm{O}_{5}$ in $\mathrm{B}$-II, therefore, the electrochemical performance (especially long-term durability) is not affected.

In order to identify all the possible crucial factors to the whole energy output, long-term durability was tested. A typical relationship of the total power output with fixed carbon content is plotted in Figure 12. It is apparent that more power is produced from carbon with a high fixed carbon content. As A-I has the highest fixed carbon content (85.8\%), it produces the highest overall power output.

\section{Conclusions}

In this study, coal samples with different properties were tested in hybrid direct carbon fuel cells (HDCFCs). Two raw anthracite coals and two bituminous coals were compared in terms of the electrochemical performance in HDCFCs. The maximum power density of the cell with anthracite coals was slightly lower than that of bituminous coals. Short term durability testing (less than 10 hours) showed that bituminous coals had a slower performance drop than anthracite coals. 
However, the total power output from anthracite coal (A-I) was better than from the bituminous coals. The HDCFCs were maintained at $20-40 \mathrm{~mA} \mathrm{~cm}^{-2}$ for over 120 hours with $1.6 \mathrm{~g}$ coal. The results showed that a high volatile matter, a high hydrogen content and a low moisture content are desirable for a short term operation, while in longer term operations, a high carbon content is preferable. This means that coal samples with an ordered crystalline structure, high carbon content, and low ash content (e. g. anthracite) will be ideal candidates for use in DCFCs.

Acknowledgement

The authors would like to acknowledge the funding support of "Efficient Conversion of Coal to Electricity-Direct Coal Fuel Cells“ (RFCR-CT-2011-00004) from the Research Fund for Coal \& Steel of the European commission. CJ acknowledges the Royal Society of Edinburgh for a RSE BP Hutton Prize in Energy Innovation.

\section{References}

1. W. W. Jacques, Harper's New Monthly Magazine, 1896-1897, 94, $144-150$.

2. W. W. Jacques, US Patent 1896, 555,511.

3. A. C. Chien, A. Arenillas, C. R. Jiang and J. T. S. Irvine, J Electrochem Sac, 2014, 161, F588F593.

4. N. Kaklidis, V. Kyriakou, I. Garagounis, A. Arenillas, DA. A. Menendez, G. E. Marnellos and M. Konsolakis, Rsc Adv, 2014, 4, 18792-18800.

5. J. Jewulski, M. Skrzypkiewicz, M. Struzik and I. Lubarska-Radziejewska, International Journal of Hydrogen Energy, 2014, 39, 21778-21785.

6. L. Deleebeeck, D. Ippolito and K. K. Hanser, JElectrochem Soc, 2015, 162, F327-F339.

7. J. A. Allen, M. Glenn and S. W. Donne, Ypower Sourices, 2015, 279, 384-393.

8. C. G. Lee and W. K. Kim, International (ourna of Hydrogen Enekgy, 2015, 40, 5475-5481.

9. I. Lee, S. Jin, D. Chun, H. Choi, S. Lee, K. Lee and J. Yoo, Sctence Ghina-Chemistry, 2014, 57, 1010-1018.

10. H. Ju, J. Eom, J. K. Lee, H. Choi, T. H. Lim, R. H. Songand J.)Lee, Electrochimica Acta, 2014, 115, 511-517.

11. X. Li, Z. H. Zhu, R. De Marco, Bradley and A.Dicks, DPower Sources, 2010, 195, 4051-4058.

12. N. Kaklidis, I. Garagounis, W Ky kiakou, V.Besikiotis, A. Arenillas, J. A. Menéndez, G. E. Marnelløs and M. Konsolakis, Internationo Sournal of Hydrogen Energy, 2015, 40, 1435314363.

13. A. C. Rady, S. Giddey, A. Kulkarni S. P. S. Badwal and S. Bhattacharya, Electrochimica Acta, 2014, 143, 278-290.

14. A. C. Rady, S. Giddey, A. Kulkarmi, S.P. S. Badwal and S. Bhattacharya, Electrochimica Acta, 2015, 178, $721-731$.

15. C. Jiang, J. Mla, A. AreniNasand J. T. S. Irvine, Ecs Transactions, 2013, 57, 3013-3021.

16. C. Jiang, 1. Ma, A. Arenillas and J. T. S. Irvine, Ecs Transactions, 2014, 59, 281-288.

17. C. R. Jiang, J. J. Ma, A. D. Bonaccorso and J. T. S. Irvine, Energy \& Environmental Science, 2012, 5, 6973-6980.

18. J. P. Kim, H. K. Choi, Y. J. Chang and C. H. Jeon, International Journal of Hydrogen Energy, 2012, 37, 11401-11408.

19. K. Xu, C. Chen, H. Liu, Y. Tian, X. Li and H. Yao, International Journal of Hydrogen Energy, 2014, 39, 17845-17851.

20. E. K. Lee, H. H. Chun and Y. T. Kim, International Journal of Hydrogen Energy, 2014, 39, 16541-16547.

21. L. Deleebeeck, A. Arenillas, J. A. Menendez and K. K. Hansen, International Journal of Hydrogen Energy, 2015, 40, 1945-1958.

22. M. R. Predtechensky, Y. D. Varlamov, S. N. Ul'yankin and Y. D. Dubov, Thermophys Aeromech+, 2009, 16, 601-610.

23. A. C. Rady, S. Giddey, A. Kulkarni, S. P. S. Badwal, S. Bhattacharya and B. P. Ladewig, Appl Energ, 2014, 120, 56-64. 


\section{Captions}

Figure 1 FTIR spectra of all the coal samples. (a) A-I, (b) A-II, (c) B-I, (d) B-II

Figure 2 XRD patterns of all coal samples. (a) A-I, (b) A-II, (c) B-I (d) B-II

Figure 3 Particle size distributions of the milled and the non-milled A-I, the raw coal is A-I and the milled coal is A-I-M.

Figure 4 Influence of particle size of the coal sample on the durability of the cell. (a) Cell I with A-Kas the fuel, insert graphs show the spectra of Cell I taken at the start point A and after two hours at B; (b) Cell II with A-I-M the fuel, insert graphs show the spectra of Cell II taken at the start point $\mathrm{C}$ and after two hours at $\mathrm{D}$.

Figure 5 Impedance spectra of the cells with different pre-milling processing. (a) Cell II with A-I-M fuelorounded by hand in a mortar with carbonate, this impedance data is the same as the impedance spectra shownin Figure 4 (Inserted graph, C); (b) Cell III with A-I-M fuel milled with carbonate in a bottle with zirconia milling mediunin acetone solvent.

Figure 6 Electrochemical performance of the cells using different coal samples as fuels. (a) ac Mpedance spectra of the cells, tested in open circuit conditions at $750{ }^{\circ} \mathrm{C}$; (b) the current-density and voltage, current density and power density of the cells operating at the same temperature.

Figure 7 Durability over a period of 24 hours of the cells at $0.7 \mathrm{~V}$ with different types of coal sanples as fuels in the presence of nitrogen in the anode chamber.

Figure 8 Influence of the purge gas on the durability of Cell VII at $0.7 \mathrm{~V}$ with A-I-M as the fue the cell was operating in nitrogen for the first two hours and then without any purge gas over the remaining test time.

Figure 9 Durability of the cells at $0.7 \mathrm{~V}$ with differen types of colsamples as fuets without purge gas over a long period. The testing schedule is a loop as follows: the cell is opepating ate.7 for 2 hours and then returns to open circuit conditions for 20 minutes and then another loop as above. The noise is fyom the interruption of the durability test by an ac impedance every two hours. Note: the data before 24 hourswepe recorded in Figute 7 .

Figure 10 Durability of Cell VII at $0.7 \mathrm{~V}$ with A-I-Mas the fur. The testing schedule is a loop as follows: the cell is operating at $0.7 \mathrm{~V}$ for 2 hours and then returns tojopen circuitconditions for 20 minutes and then another loop as above. The Noise is from the interyuption of the durability test as shomabove.)

Figure 11 Relation of poyer output over a period of 24 hourswith coal compositions, (a) Volatile matter; (b) ratio of hydrogen toearbon, c) moisture; (d) sulphur (denter content; (f) Fixed carbon. Note: data of power output over 24 hours aequired from Figure 7, total power output of $840 \mathrm{~mA} \mathrm{~h}, 664 \mathrm{~mA} \mathrm{~h}, 761 \mathrm{~mA} \mathrm{~h}$, and $785 \mathrm{~mA} \mathrm{~h}$ obtained from Cell III, Cell IV, Cell V and Cell Whespective Note that in all cases active area was $1 \mathrm{~cm}^{2}$.

Figure 12 Correhation between totahomer oytput and fixed carbon content, Note: data of total power output of $1.6 \mathrm{~g}$ coal acquired fyom Figure 9. 


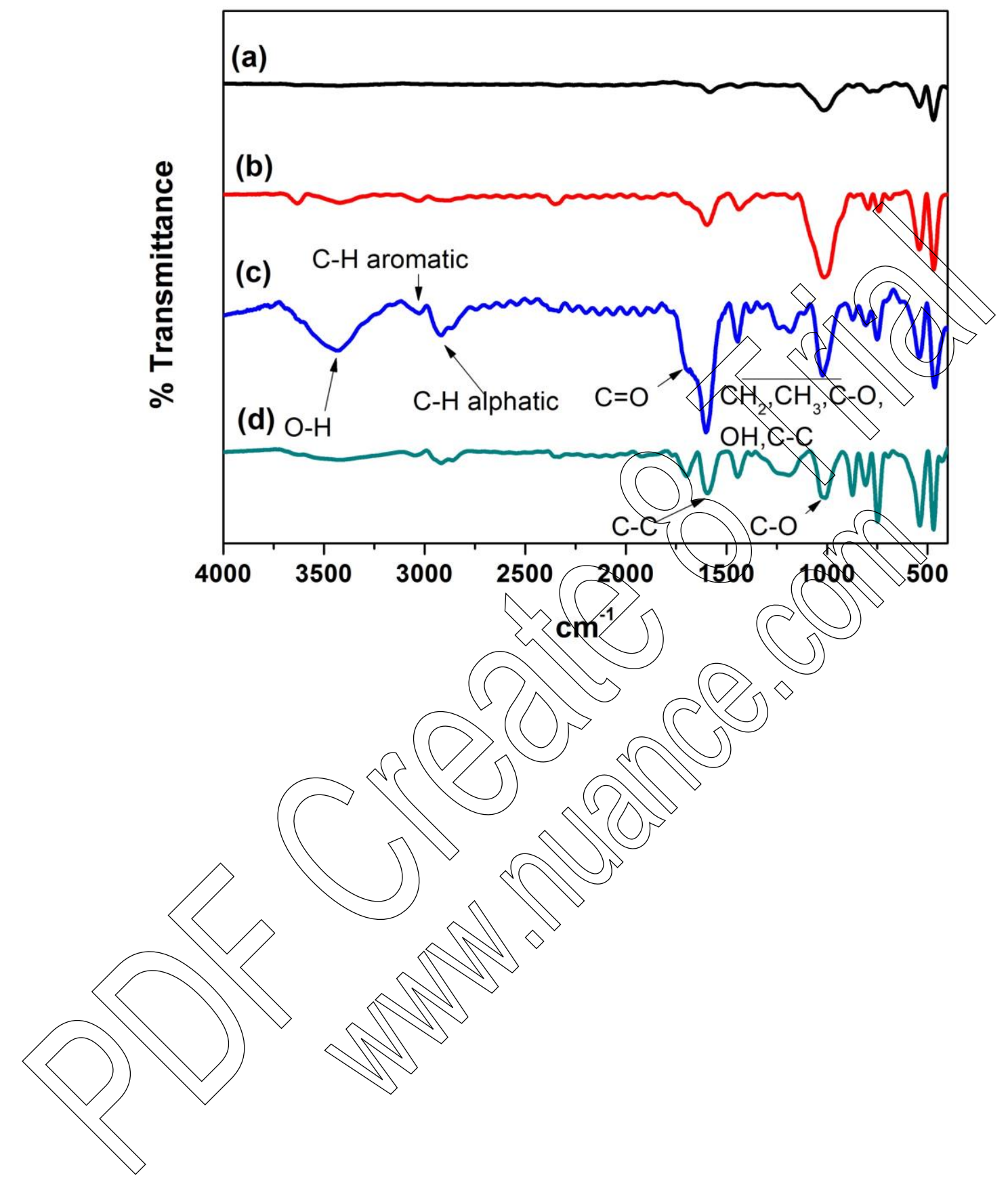




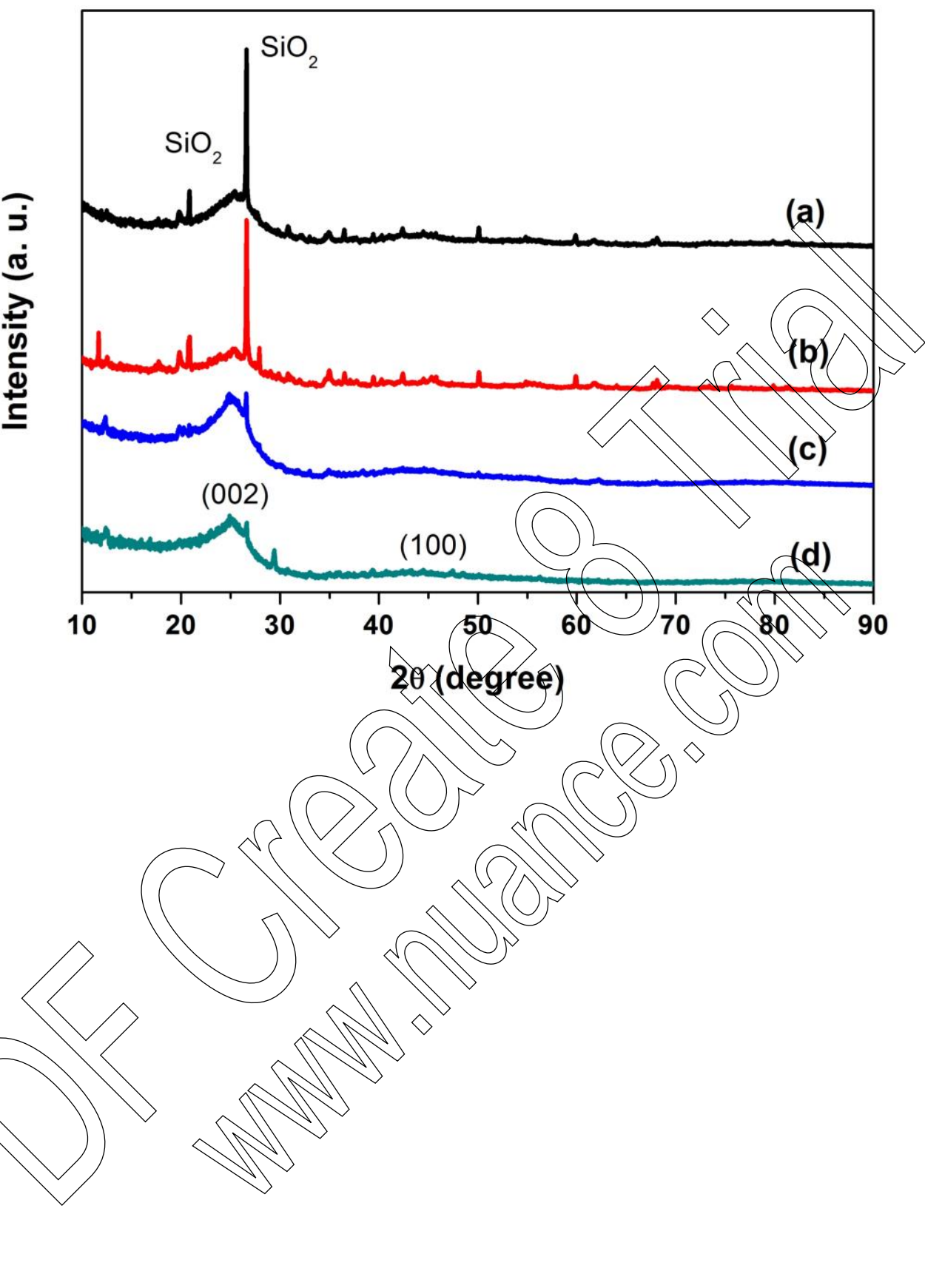



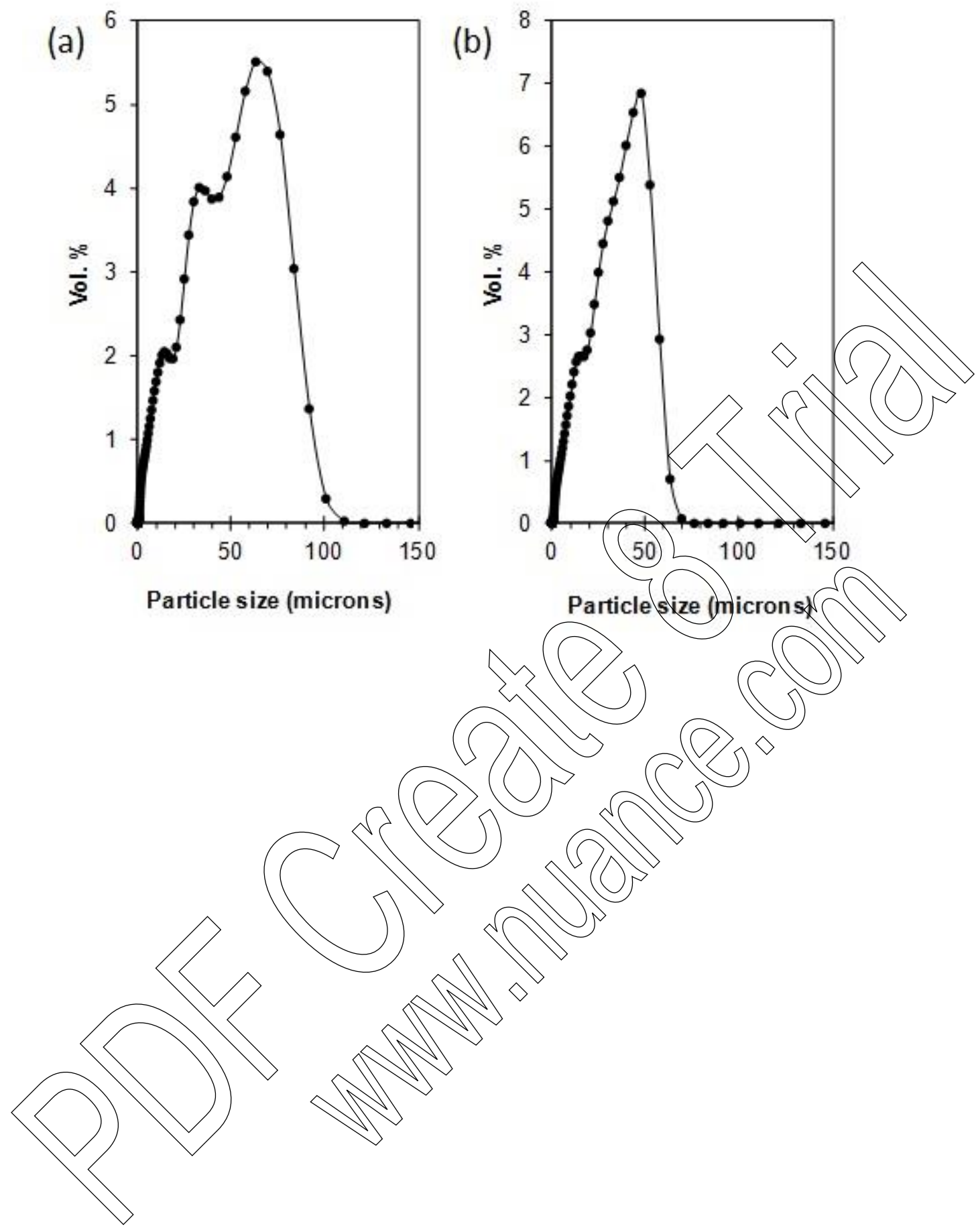


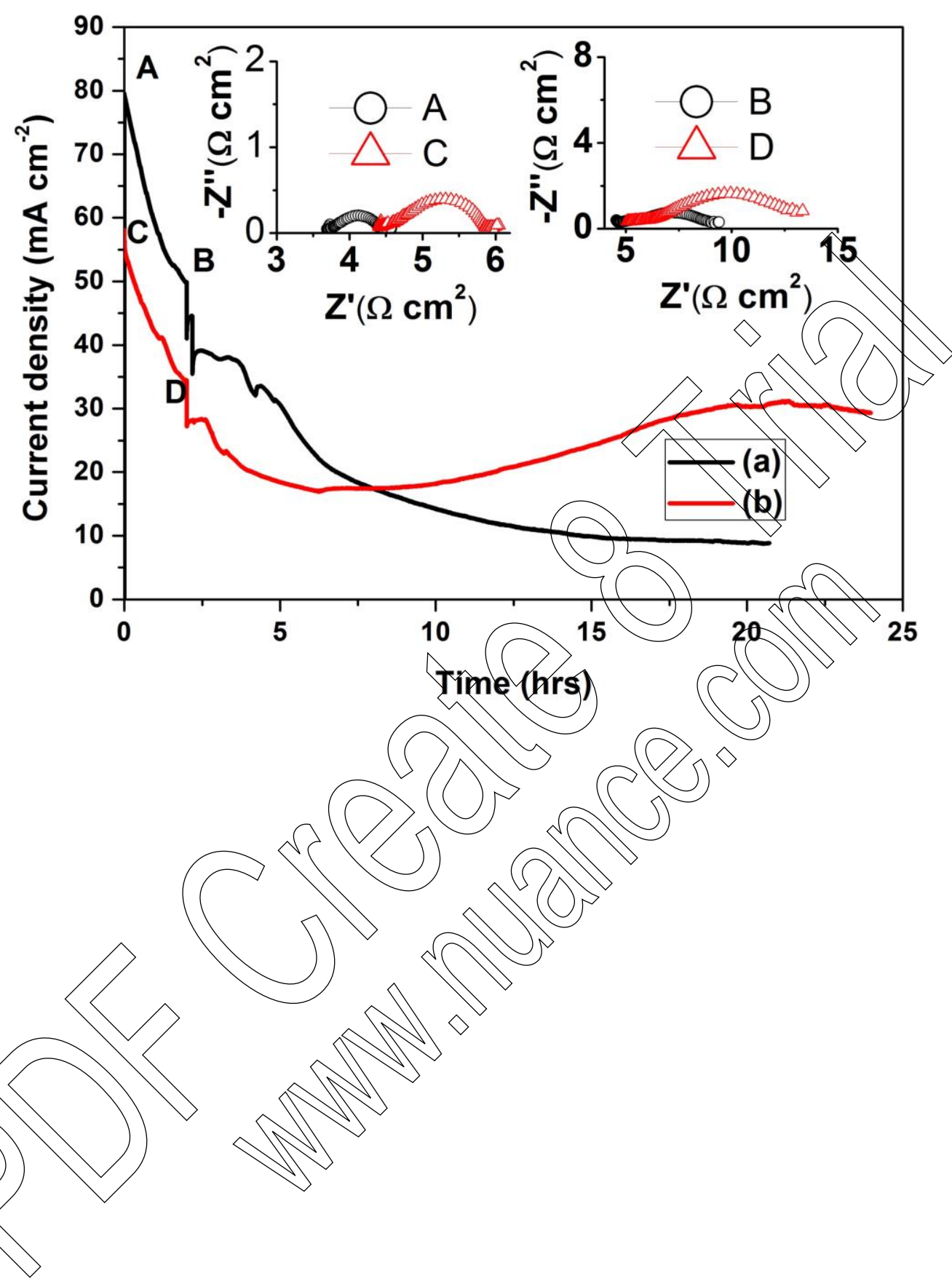



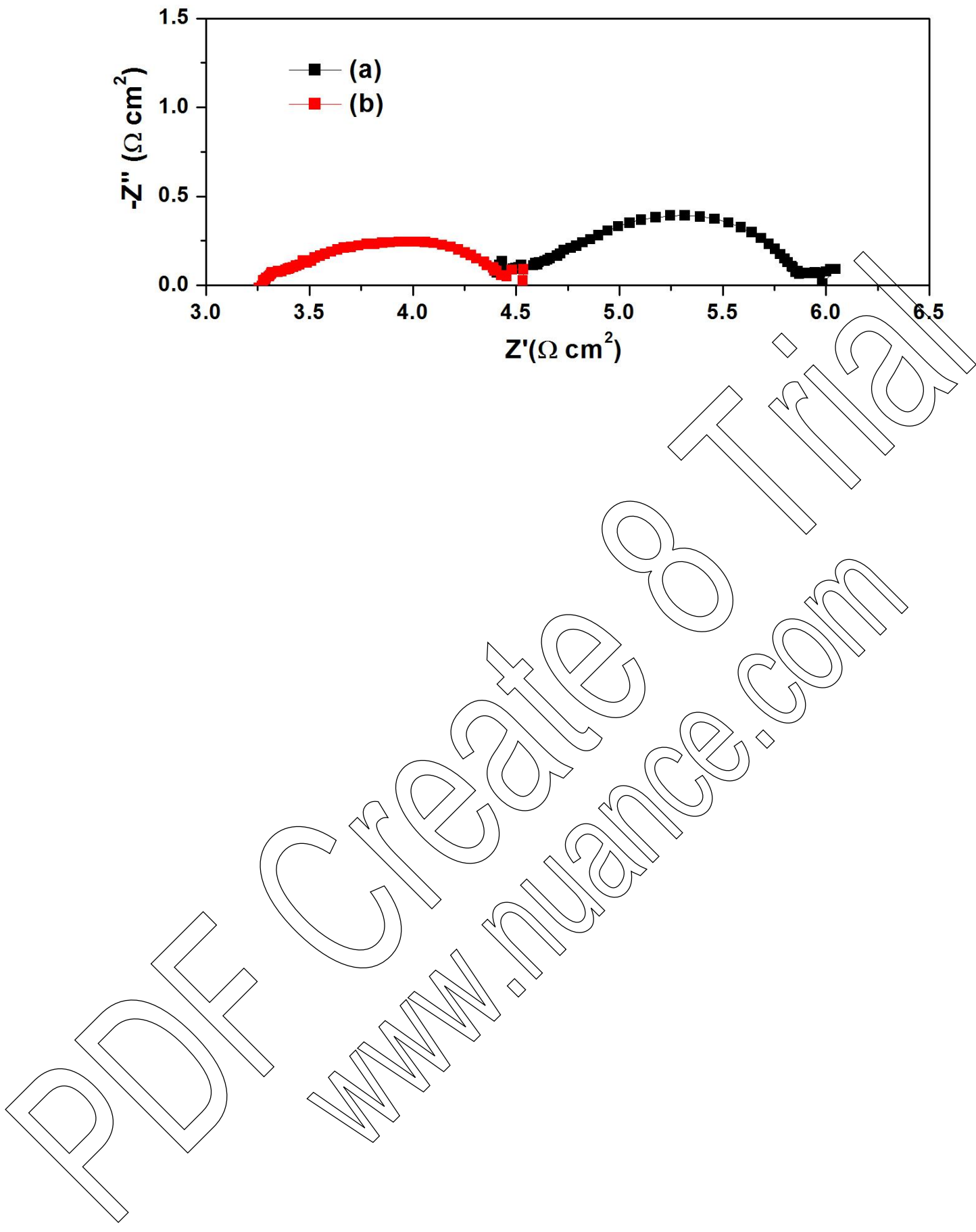

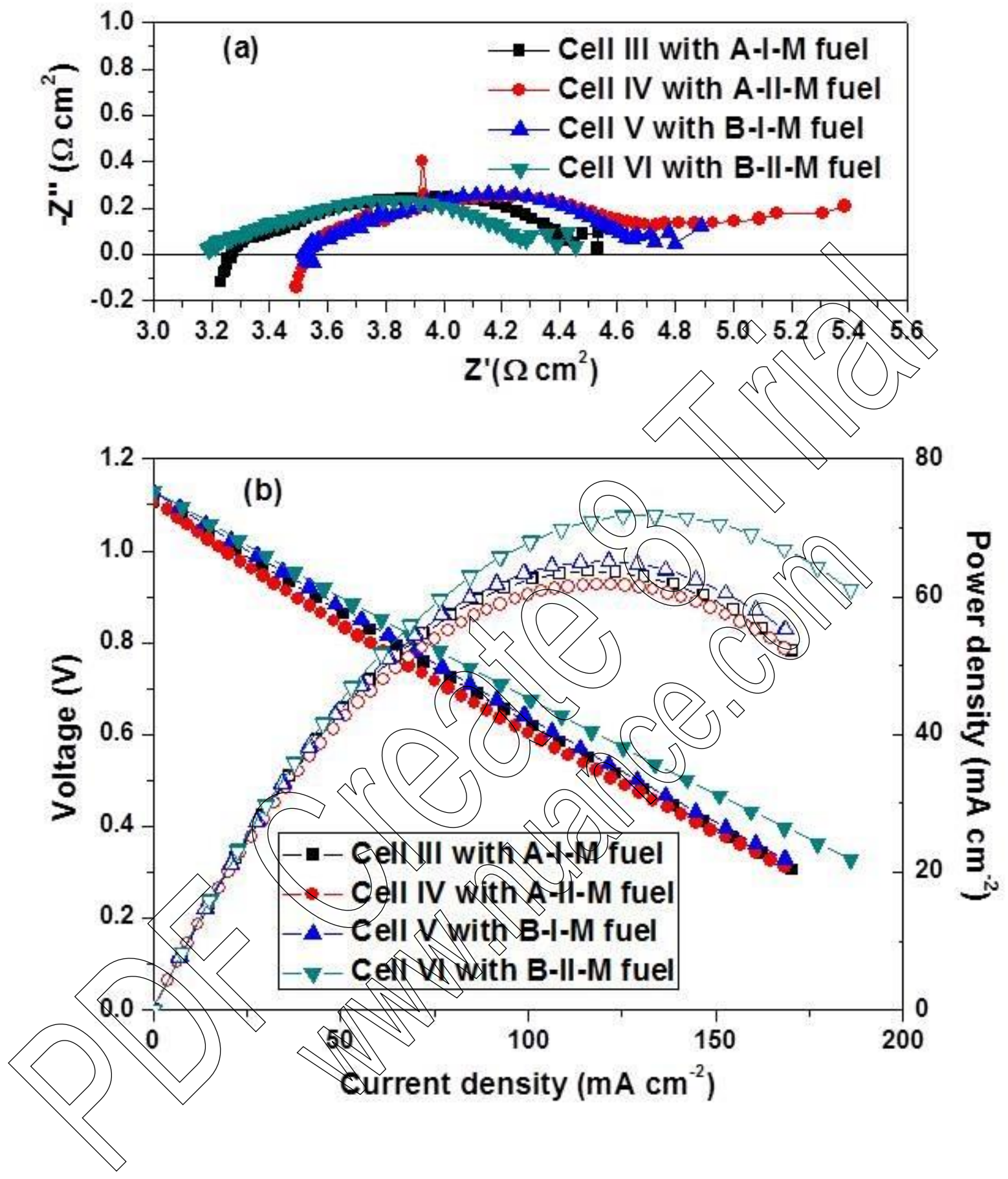


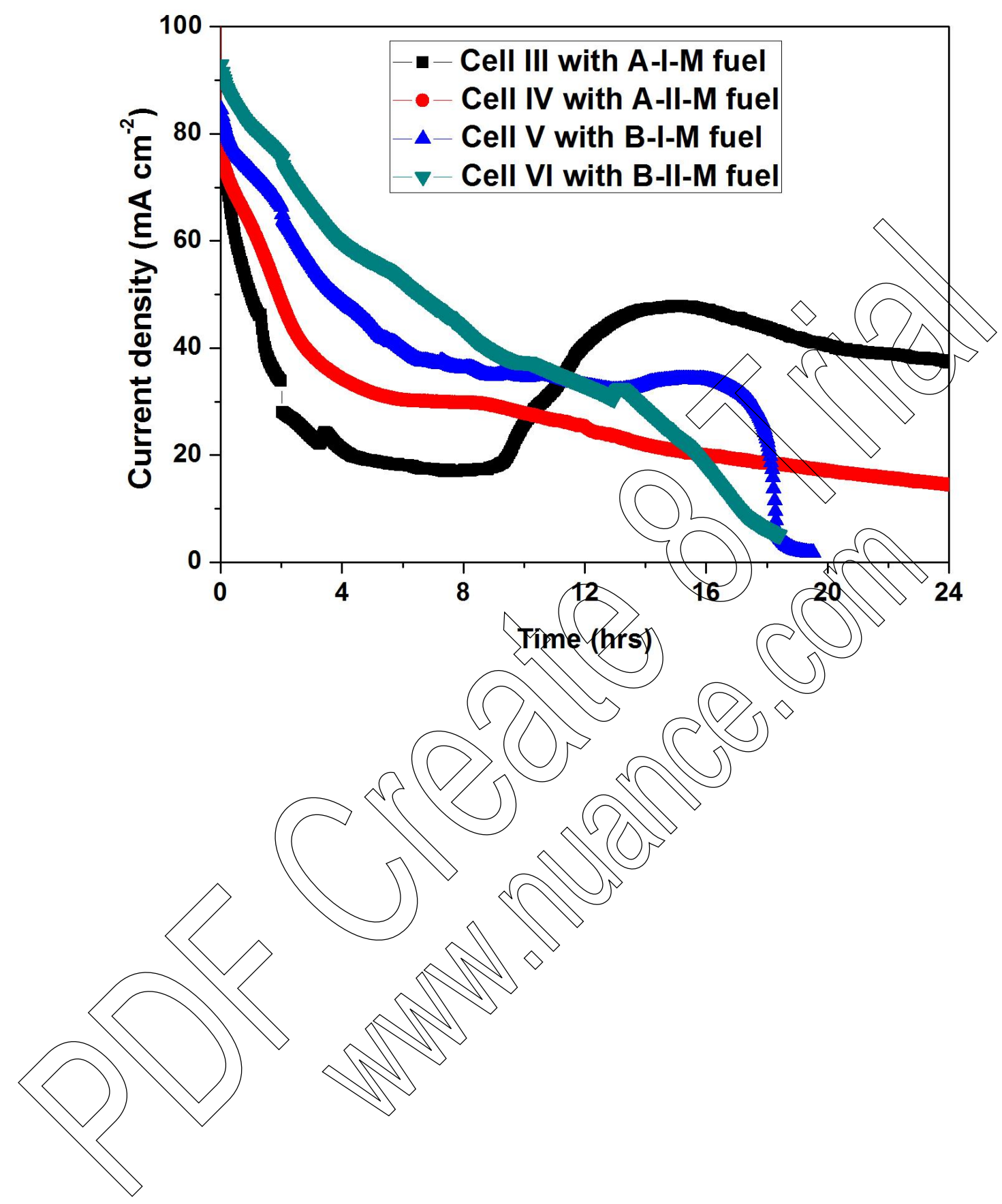




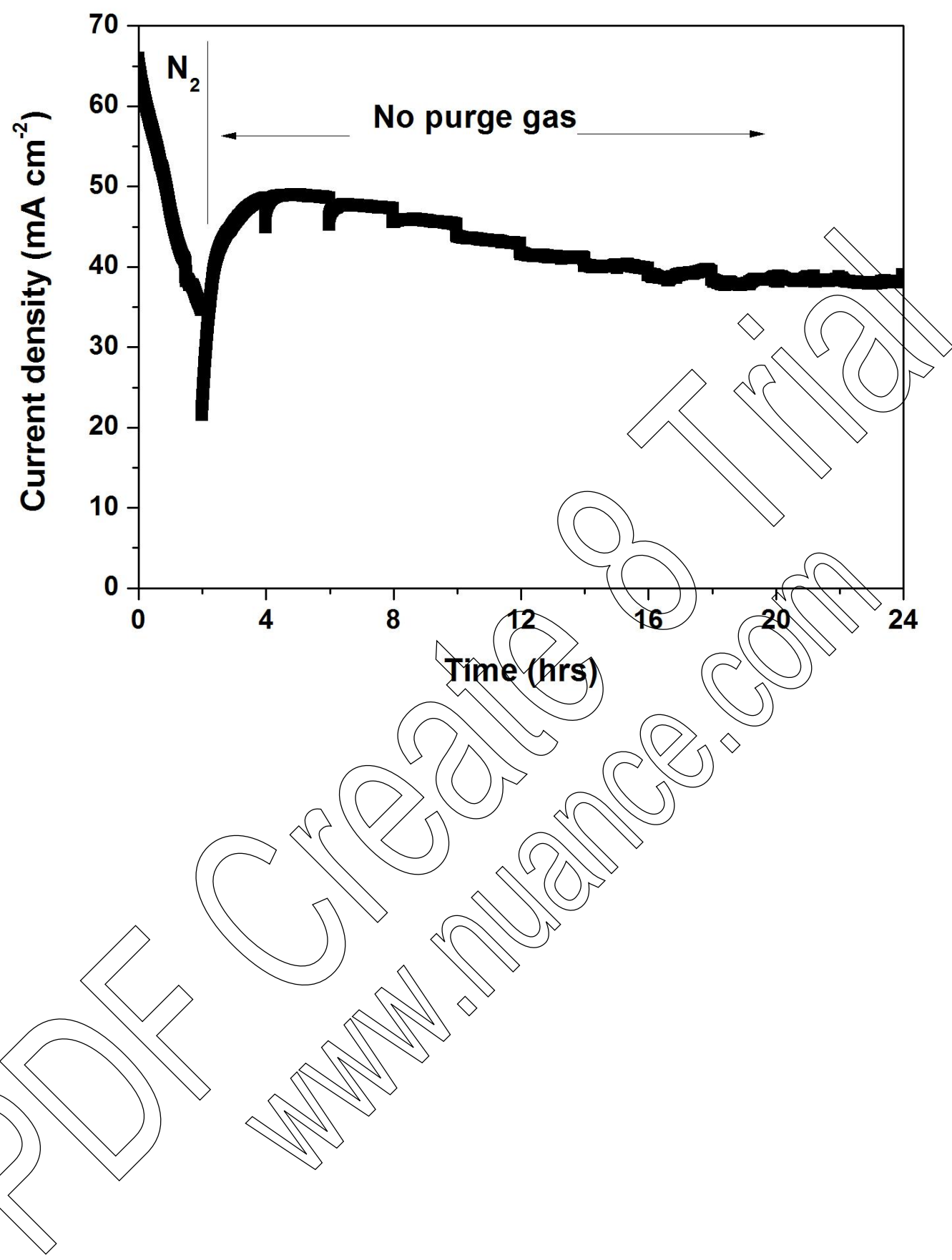




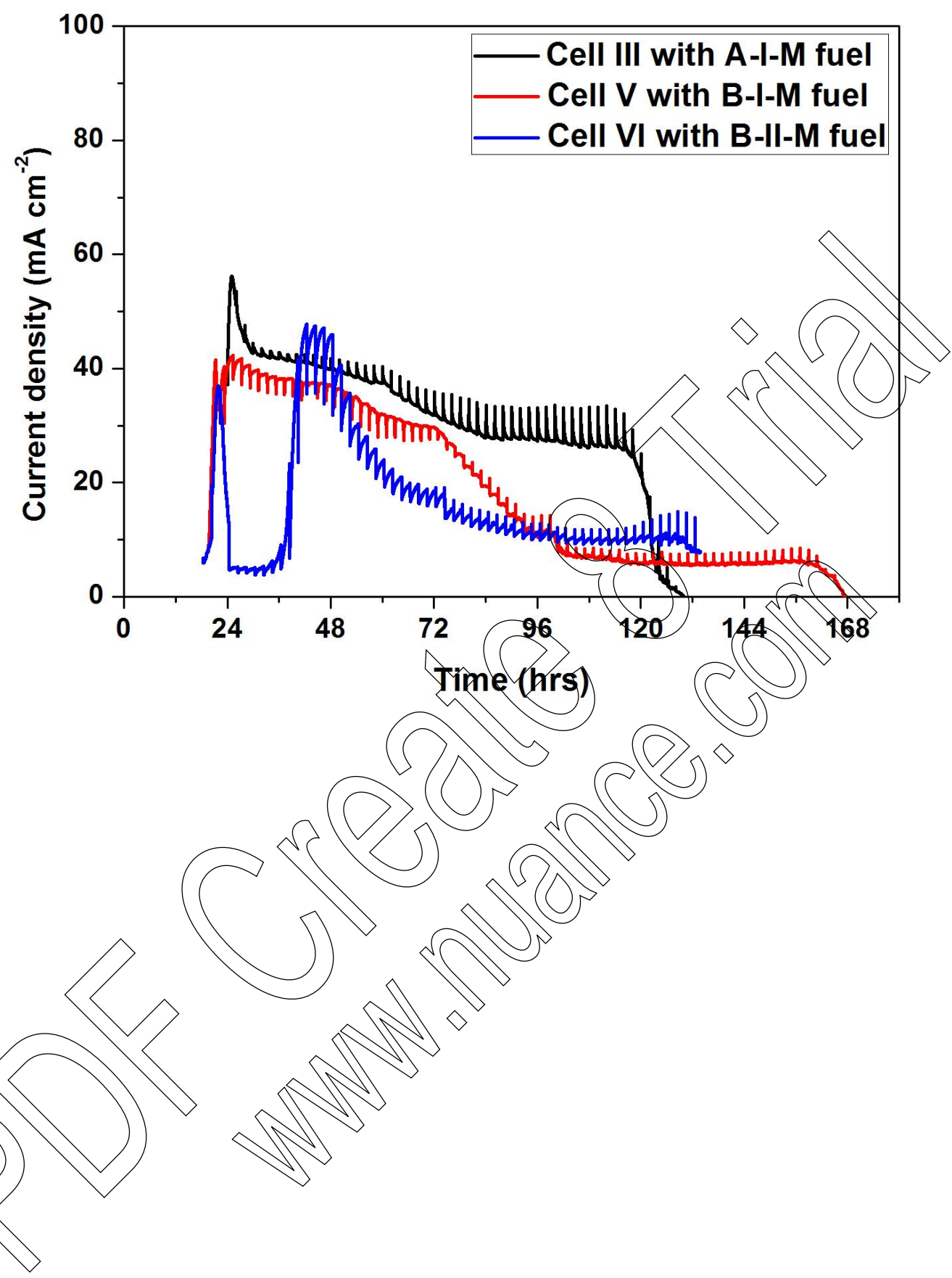




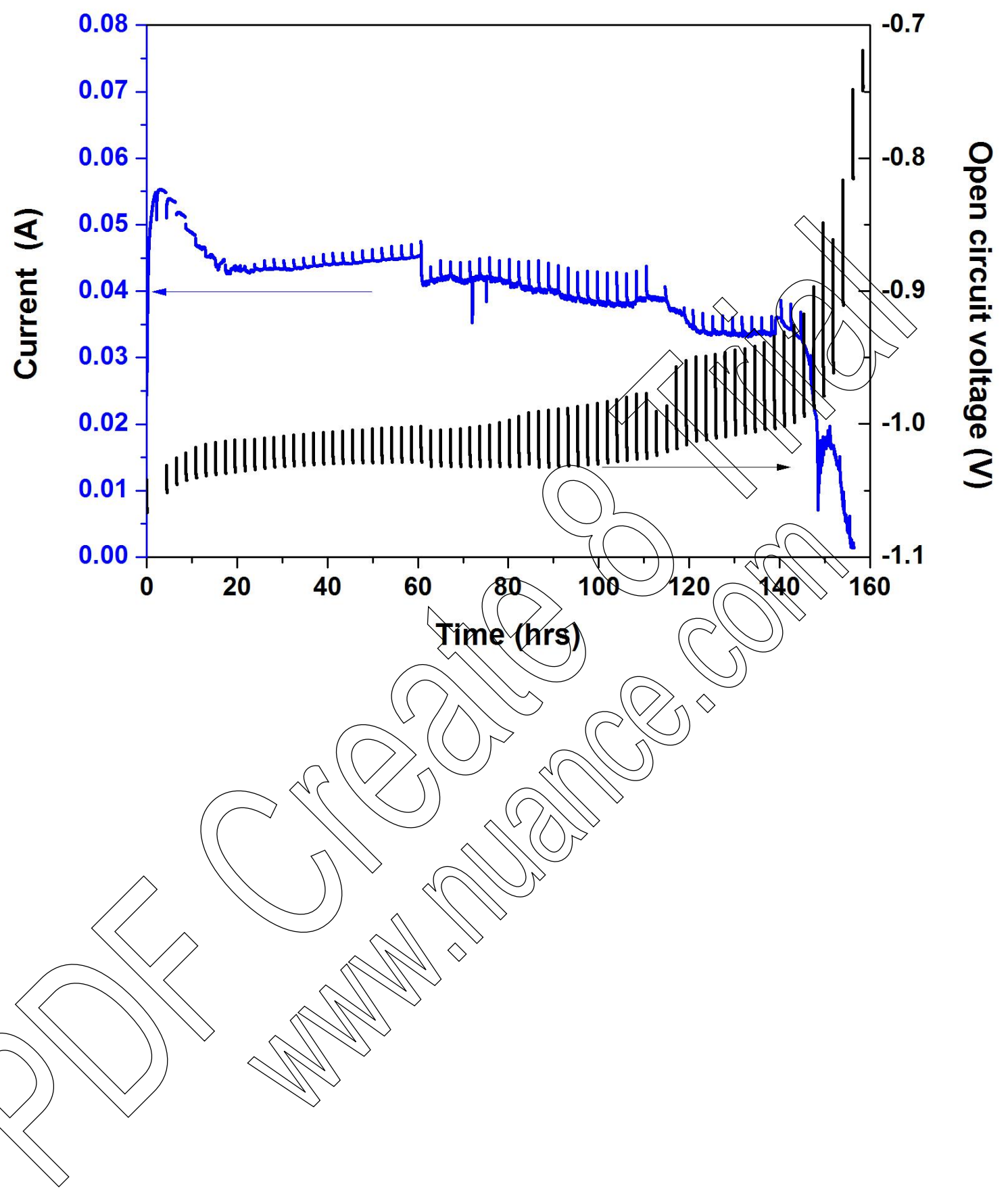




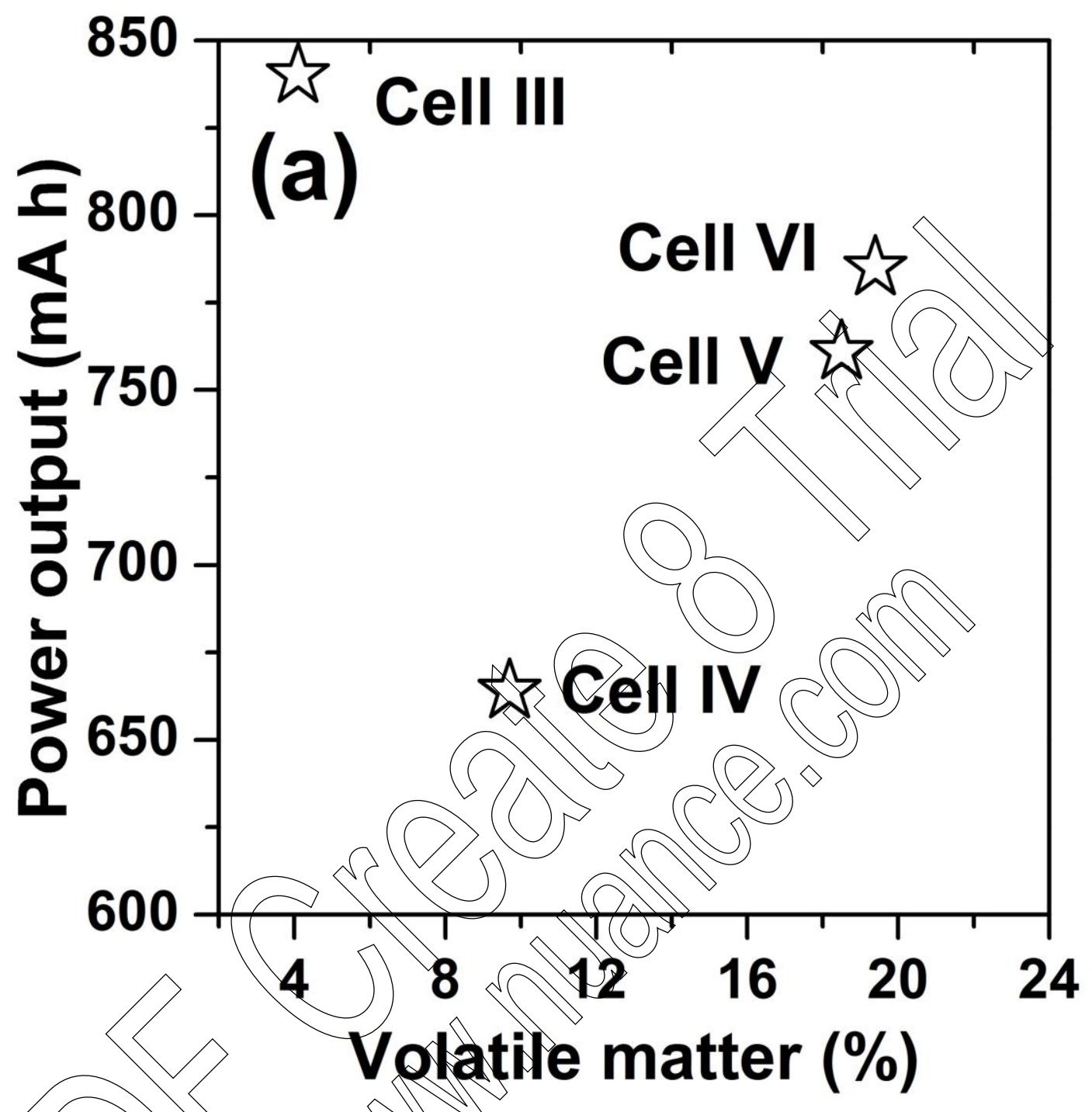




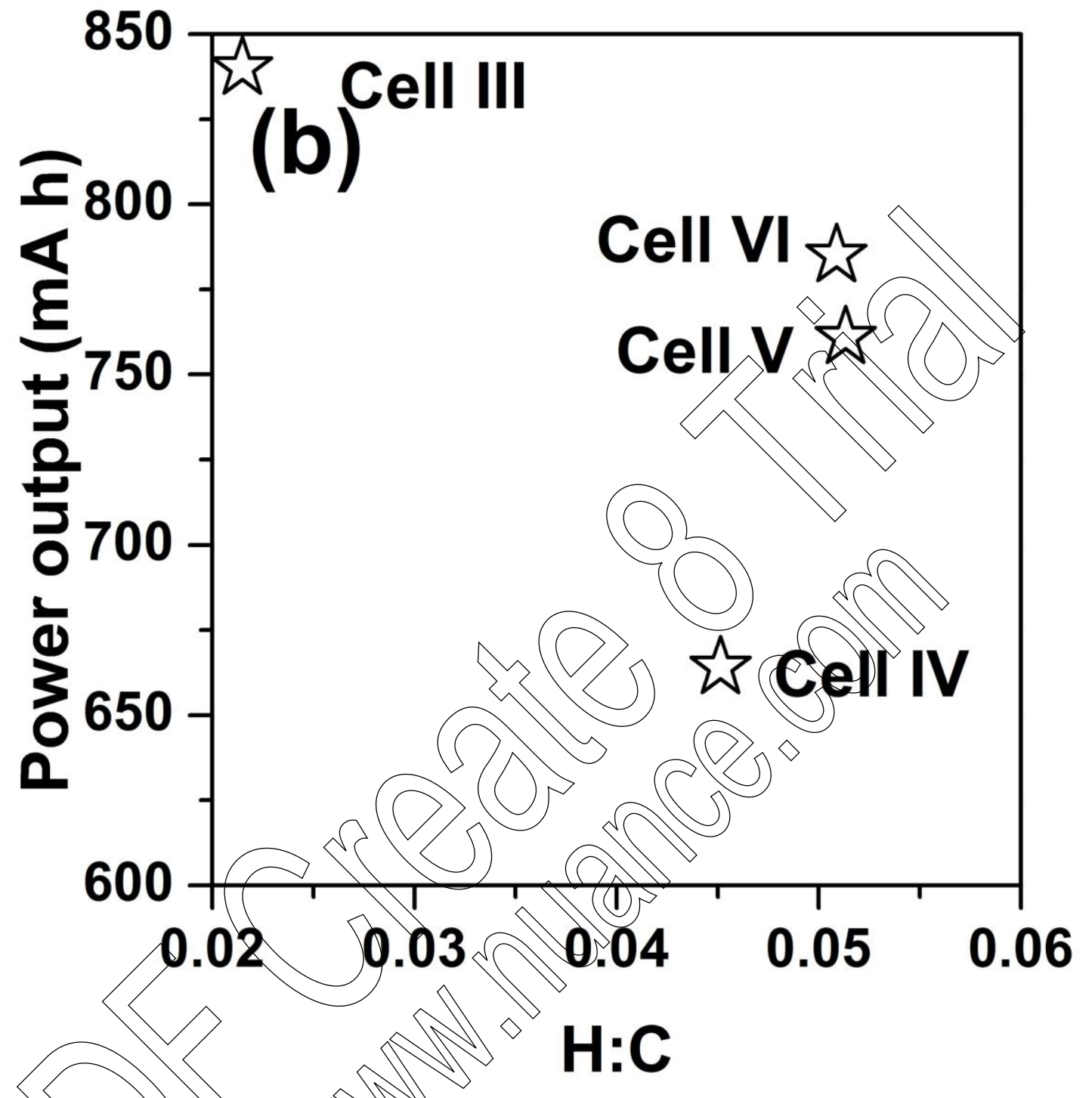




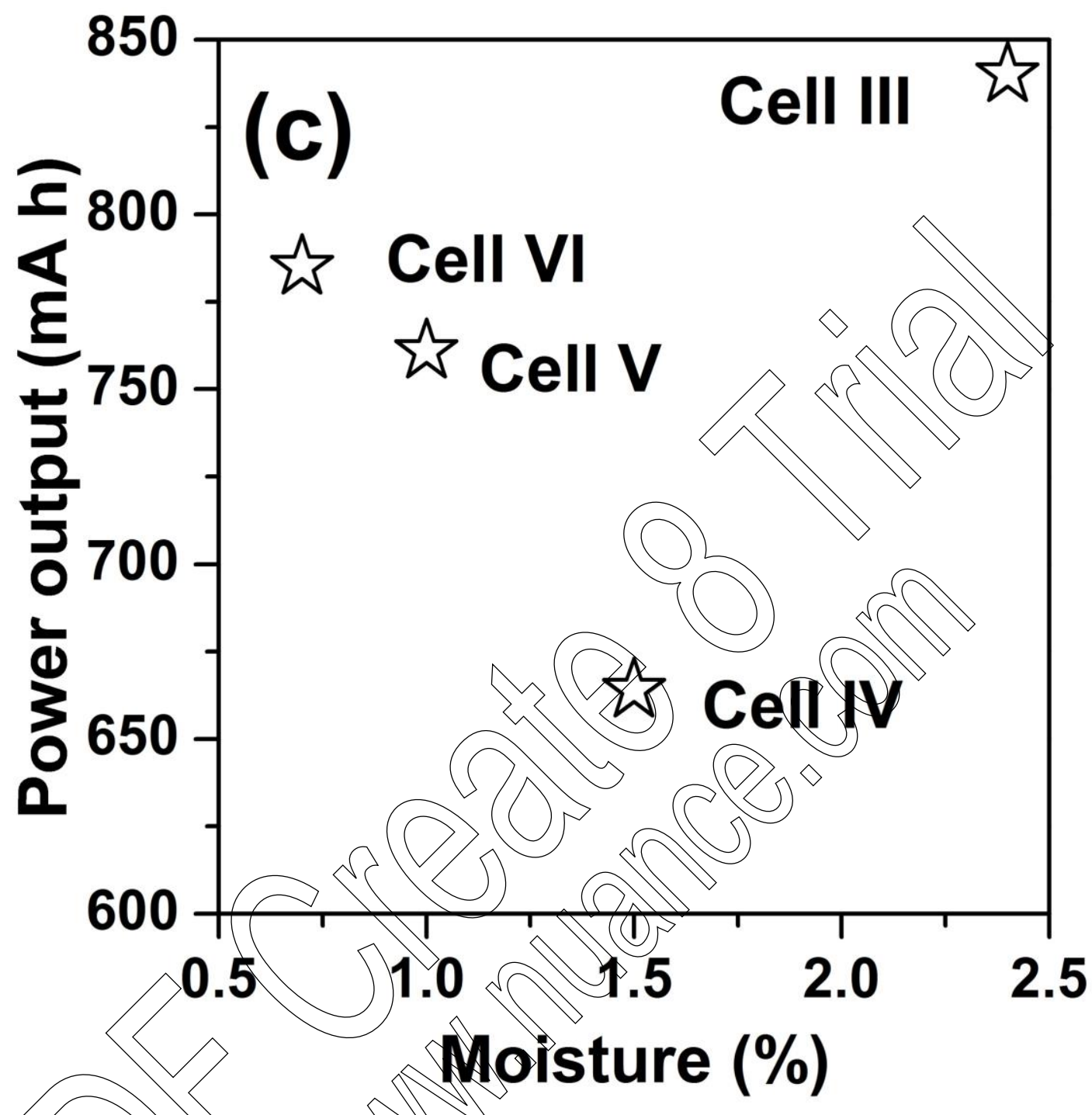




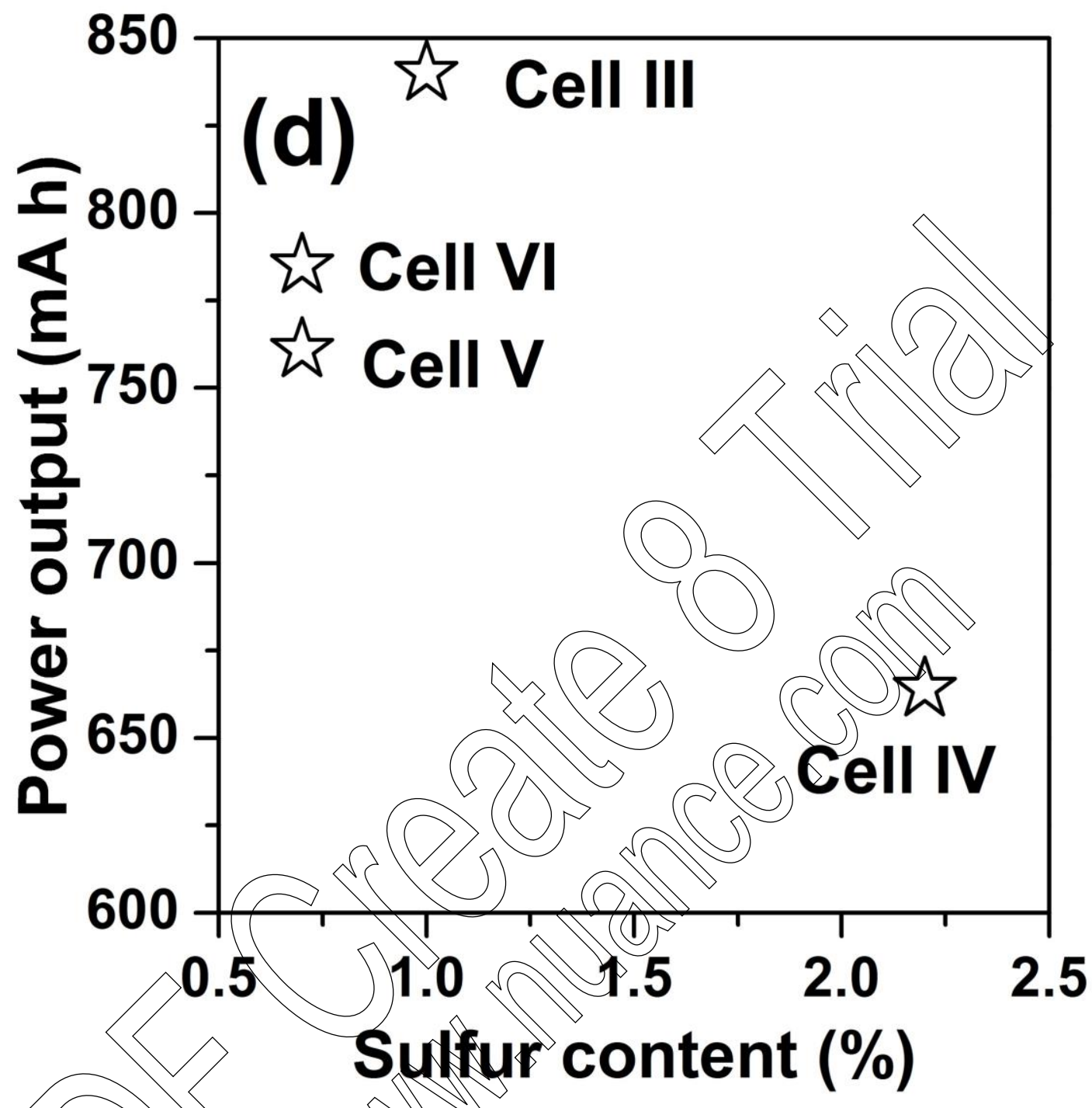




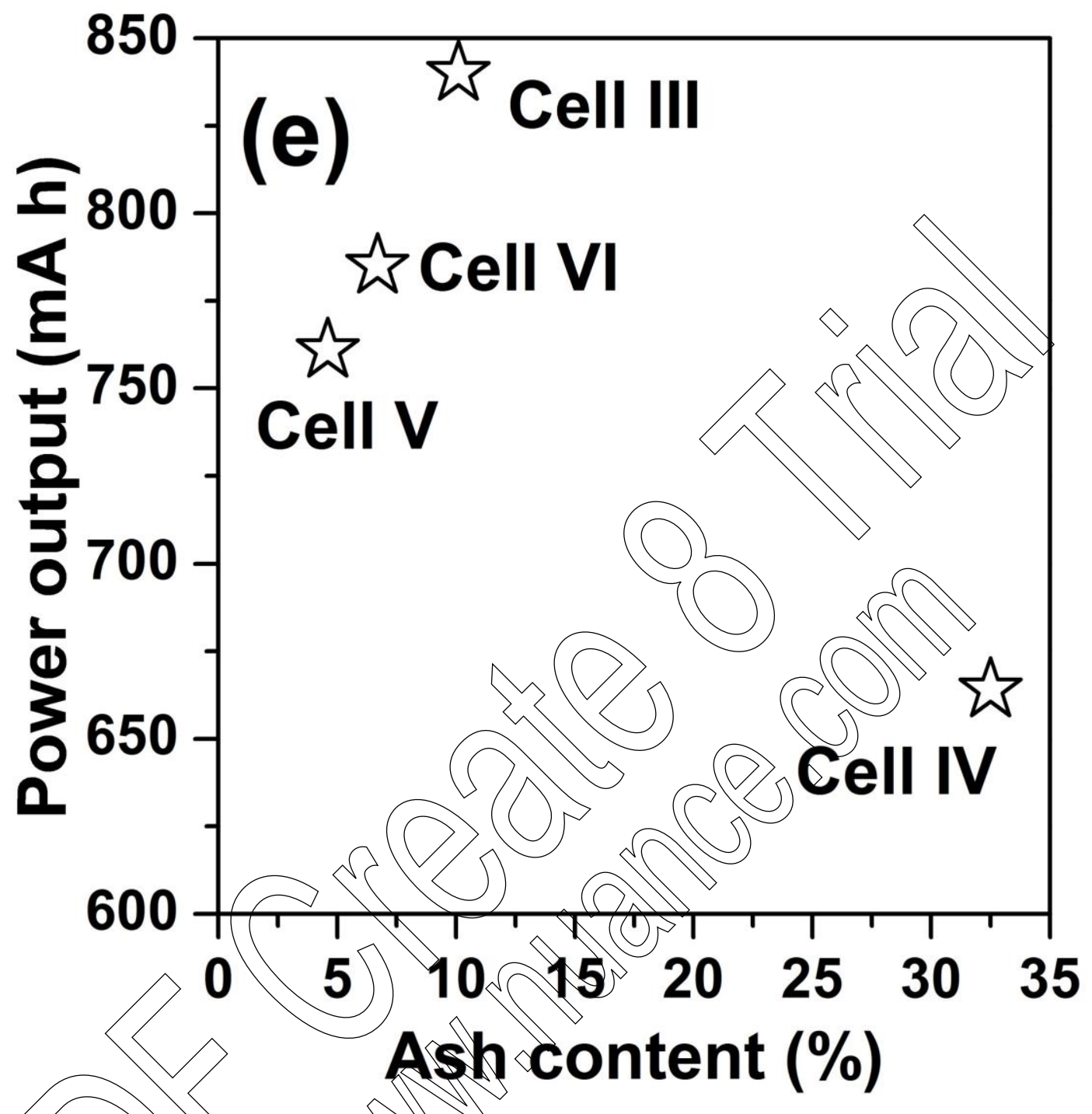




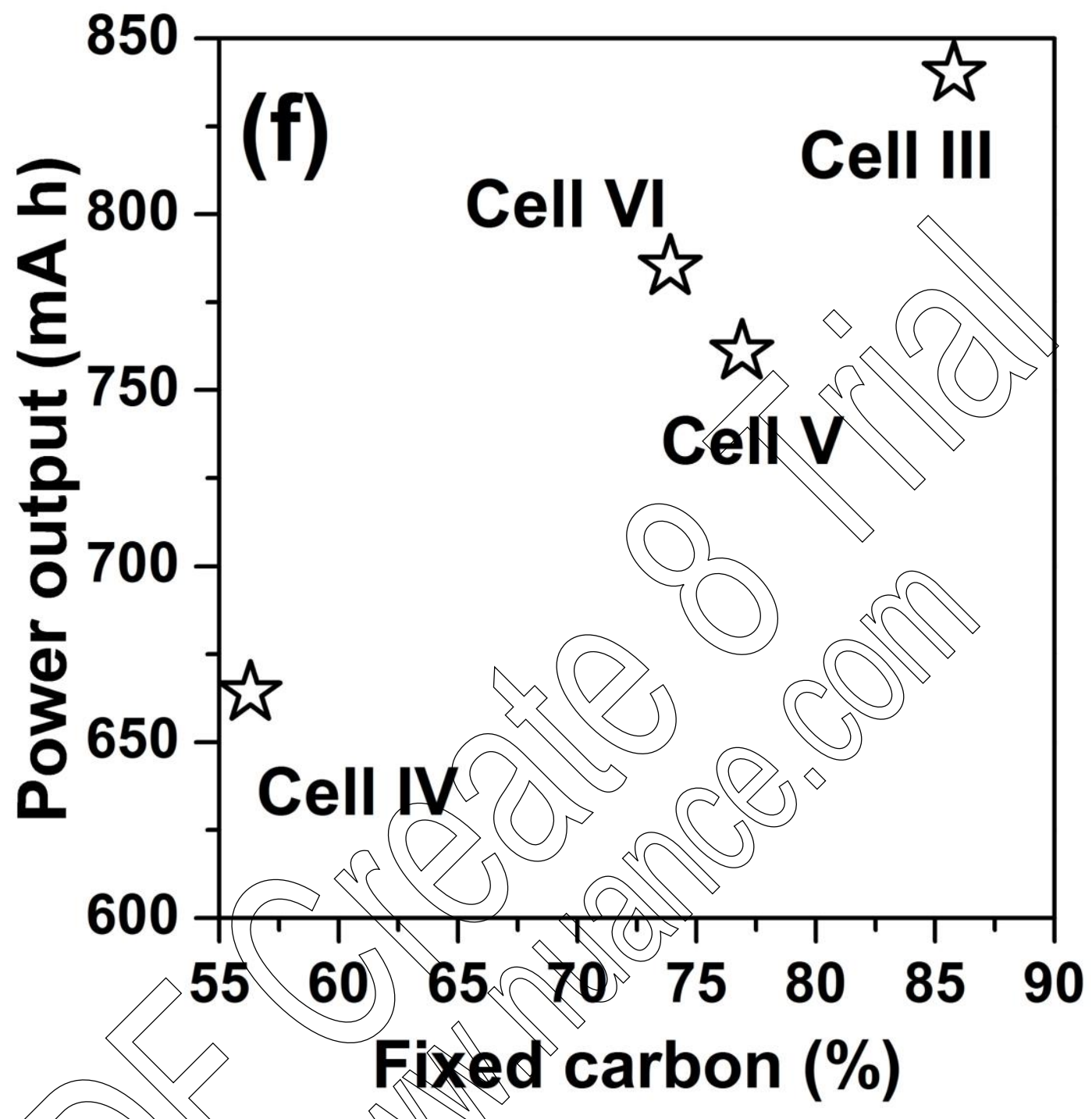



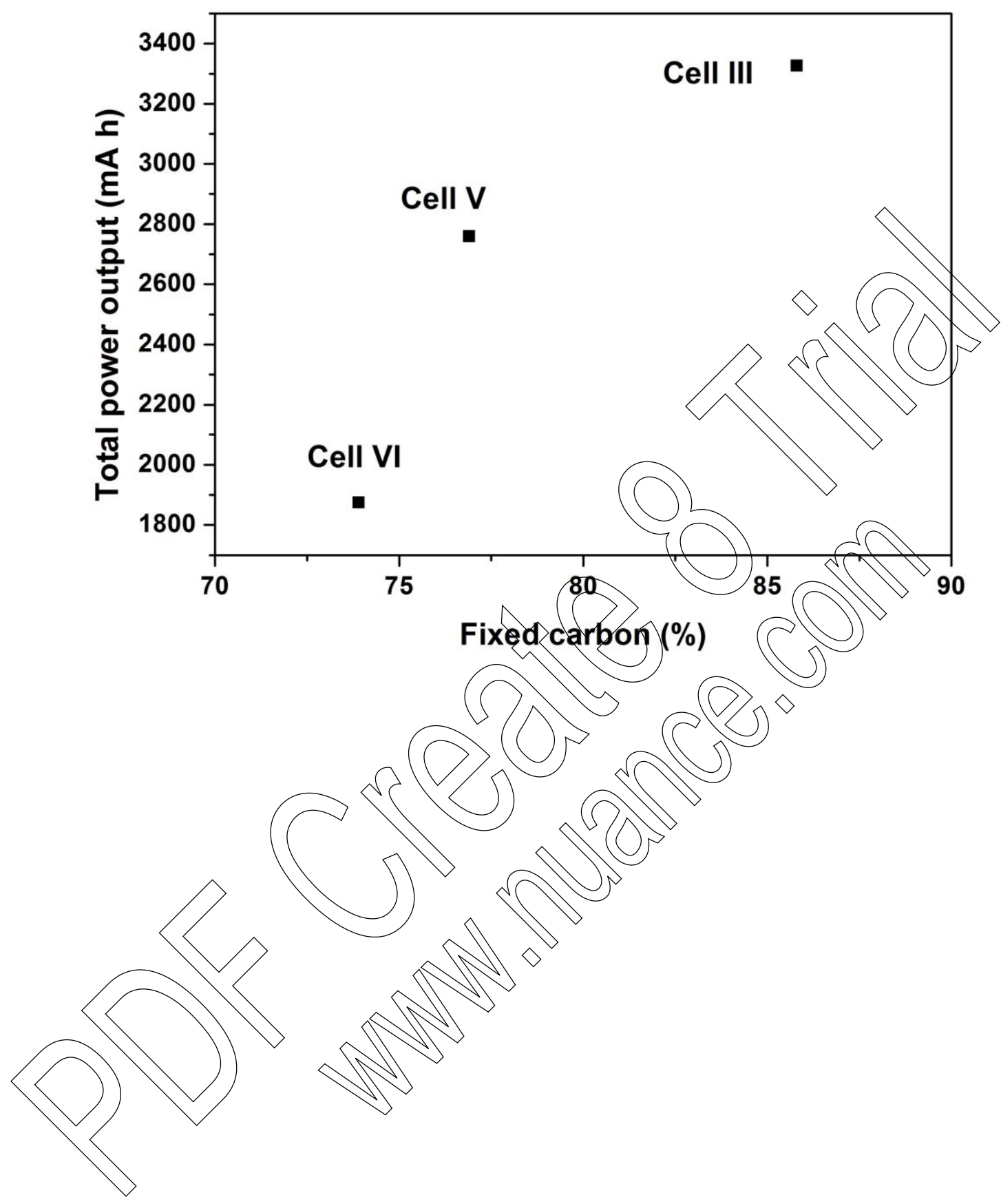